\title{
ELIDAN Certificate: BEHAVIOR is the key to save places from Covid-19
}

Journal of Bioscience \& Biomedical Engineering

Research Article

"CRUZ-RODRIGUEZ L. ${ }^{(1,2,3,4)}$, RODOLFO BAREA ${ }^{(2,4)}$, ZAYAS TAMAYO A.M. ${ }^{(5)}$, HOCHWIMMER B. ${ }^{(6)}$, BEN HADDA $T_{0}{ }^{(7,8)}$, ALMALKI F. A. ${ }^{(8)}$, LAMBERT BROWN ${ }^{(9)}$, PELAEZ FIGUEROA Y. ${ }^{(2,4)}$, SANCHEZ BATISTA L.(5) and WARAD I. ${ }^{(10)}$

${ }^{1}$ CEO, ELIDAN genome SAS, 1 avenue du Lycée, 77130

Montereau Fault Yonne, France.

${ }^{2}$ CEO, ELIDAN Dynamic LLC, 1602 Windermere Way, Tampa, FL,33619, USA.

${ }^{3}$ ExCELab Co. Ltd., Manager Director of Environmental

Biotechnology Department, Jamaica.

${ }^{4}$ ELIDAN america LLC, $6826 \mathrm{NW} 77$ th CT, Miami, FL, USA.

${ }^{5}$ ExCELab Co. Ltd., Environmental Biotechnology Department, Jamaica.

${ }^{6}$ CEO, Hochwimmer B. \& Asso. Pty Ltd: Consultants in Exploration, Mining and Environmental Geology, NSW, Australia. ${ }^{7}$ Laboratory of Applied Chemistry \& Environment, Faculty of Sciences, University Mohammed the first, BP 524, 60000, Oujda, Morocco.

${ }^{8}$ Department of Pharmaceutical Chemistry, Faculty of Pharmacy, Umm Al-Qura University, Makkah Almukkarramah, 21955, Saudi Arabia.

${ }^{9}$ CEO, Family Physician, FCMC \& ExCELab Co. Ltd, Jamaica.

${ }^{10}$ Department of Chemistry and Earth Sciences, PO Box 2713,

Qatar University, Doha, Qatar.

\author{
"Correspondence author \\ Prof. Dr. CRUZ-RODRIGUEZ Luis \\ ELIDAN America LLC \\ $6826 \mathrm{NW} 77$ th CT \\ Miami, FL, \\ USA \\ E-mail : lcr@elidan-genome.com \\ luis.cruzrguez@gmail.com
}

Submitted : 1 July 2020 ; Published : 20 July 2020

\begin{abstract}
According to the World Health Organization (WHO), viral diseases continue to emerge and represent a serious issue to public health. In the last twenty years, several viral epidemics such as the severe acute respiratory syndrome coronavirus (SARS-CoV) from 2002 to 2003, and H1N1 influenza in 2009, have been recorded. The new coronavirus, formed a clade within the subgenus Orthocoronavirinae, sarbecovirus subfamily. The first time these cases were published, they were classified as "pneumonia of unknown etiology." The question then became: are future epidemic risks amenable to forecast from identifiable triggers? Of immediate concern was the integrated research on closed spaces; where they in fact favorable or not to virus transmission subject to certification? We are currently opening diverse research in viral Medical Geology studies, as a new discipline. At present, there appears to be an emergent need for society to be educated on both existing in a world with Covid-19, while simultaneously learning how to prevent the spread of the pandemic. It is certainly important, yet has become insufficient, to impose physical distancing among people, isolation of patients, coughing "vampire" style into your elbow or continuing the usage of hand disinfectants and hand washing. The goal of this most recent work is to prepare a safety certificate for closed spaces which allows us to mandate the minimum number of people who may be present (altogether) with the minimum risk in values of viral transmission. It analyzes four key parameters in the propagation of Covid-19. The Viral Transmission in selected enclosed spaces was calculated according to the mathematical algorithm proposed by Prof. Dr. Luis CRUZ RODRIGUEZ. The Covid-19 pandemic has led to a true global public health crisis as well as a devastating financial recession, affecting the entire world. Here we have proposed a certification entitled: "Elidan Certificate", depicting prolonged safety within enclosed areas, such as inside of buildings or relating to various modes of transportation, suggesting a safe number of people who may occupy those particular places. Our aim is to better understand potential dormant repositories of outbreaks and the potential spread of those repositories, together with potential geological-geogenic terrain factors in closed space and their triggers. Integrated research on closed spaces, whether favorable or not to the virus transmission, would be subject to certification, along with the imminent opening of diversity research in viral Medical Geology studies, as a new discipline is anticipated. In this regard, UVC is a well-known disinfectant for air, water and surfaces, which can help reduce the risk of acquiring Covid-19 when applied correctly. By the way, the IUVA has been given the task of bringing together a group of experts, leaders in the field, from various parts of the world with the aim of developing guides that contribute to an effective use of UVC Technologies (ELIDAN dynamic LLC).
\end{abstract}

Keywords: Covid-19, Viral Transmission, Certificate, Closed Space, Number of People, Viral Medical Geology, UVC 
According to the World Health Organization (WHO), viral diseases continue to emerge and represent a serious issue to public health. In the last twenty years, several viral epidemics such as the severe acute respiratory syndrome coronavirus (SARS-CoV) from 2002 to 2003, and H1N1 influenza in 2009, have been recorded. Most recently, the Middle East respiratory syndrome coronavirus (MERS-CoV) was first identified in Saudi Arabia in 2012. The new coronavirus formed a clade within the subgenus Orthocoronavirinae, sarbecovirus subfamily. The first time these cases were published they were classified as "pneumonia of unknown etiology." The Chinese Center for Disease Control and Prevention (CDC) and local CDCs organized an intensive outbreak investigative program. The etiology of this illness is now attributed to a novel virus belonging to the coronavirus (CoV) family, namely Covid- 19 . The genus Betacoronavirus SARS-CoV-2 is a spherical particle, ranging from $30 \mathrm{~nm}$ to $100 \mathrm{~nm}$ in diameter and is the seventh member of the Coronaviridae family (229E, OC43, NL63, HKU1, SARS-CoV and MERS-CoV with a genomic similarity of $79.6 \%)[1-4]$.

On January 10, 2020, the first 2019-nCov genome was sequenced, followed by five subsequent viral genome sequences [5]. According to the World Health Organization (WHO), viral diseases continue to emerge episodically and represent a serious issue to public health. In the last twenty years, several viral epidemics such as the severe acute respiratory syndrome coronavirus (SARS-CoV from 2002 to 2003, and H1N1 influenza in 2009), were just two such examples that have been recorded. In December 2019, a cluster of patients with pneumonia of unknown cause was linked to a seafood wholesale market in Wuhan, China. A previously unknown beta coronavirus was identified through the use of unbiased sequencing in samples from patients with pneumonia [6].

The pandemic caused by the novel virus strain Covid-19, has led to over 7,734,000 cases to date, with 429,000 fatalities, and counting, spanning across 215 countries worldwide. The clinical range and description of the disease, new diagnostics, prevention and treatment strategies are in the process of development at this very moment.

Unfortunately, insufficient research leading up to purported species-to-species viral transmission (VT) is causing some dismay to those interested in the disease. We know that VT are more frequently episodic, yet always assume a systemic closed biology. This may be a faulty discipline assumption since the increasing episodic nature of viral transmission bears scrutiny on potential physiographic-climactic links. These in turn are open to geogenic-geological connections with terrain biology and ecology.

The entire biological cycle of the virus and host, together with the evolution of the epidemic, (more specifically identifying the approximate point at which the epidemic reaches its peak) remains unknown. Terrain-controlled genomic studies in soil, plus geo-microbiology along with invertebrate Medical Geology to higher species-species transmission studies are recommended. This may extend the viral genomic phylogenetic trees beyond the species-species barriers and provide diversity of potential future impacts. Geologists have not considered the possibility of the disease spreading through air, water, or earth. The discipline of Medical Geology can translate this enigmatic situation using its potential to understand the planet and human (health) relationships [7-9].

One aim of this proposed study is to better understand potential dormant repositories of outbreaks and the potential spread of those repositories, together with potential geogenic terrain factors like closed spaces and triggers. Integrated research to certify closed spaces as favorable or not, regarding safety in terms of the virus transmission, is one of the objectives whereby we plan to offer diversity research in viral Medical Geology studies, as a new discipline [10-12].

Covid-19 is an infectious disease whose course of propagation makes it difficult to estimate. Epidemiologist Adam Kucharski has explained the factors which play an important role in the transmission of the disease through mathematical models utilizing human Coronavirus as the source of Viral Transmission (VT), and has identified in his research four parameters of contagion for this illness. His work concludes that the propagation period for the sickness requires less time than what's needed for the development of an efficacious vaccine against Covid-19 [12-15].

Kucharski has experience conducting research for a variety of diseases including Ebola, SARS and influenza, and now Covid-19. In his book The Rules of Contagion: Why Things Spread - and Why They Stop, he touches upon the rules of contagion: the "how" and the "why" of viruses' spread along their eventual cessation. Researchers [16].

Jinming Cao and co have developed a mathematical algorithm to understand the coexistence of Covid-19 corresponding with routine activities in society [17].

It is quite apparent that society will need ongoing education to coexist with the Covid-19 virus while simultaneously learning how to prevent the spread of this pandemic. Sadly, it seems that current measures are not enough: imposing physical distancing, isolation of patients, coughing "vampire" style into your elbow or the utilization of hand disinfectant and good hand-washing hygiene.

The goal of this present work is to present values of VT (viral transmission) as a reference for individuals (VTi) as well as for closed spaces where people will be present (VTcs). We have presented a unique mathematical model, unprecedented to date, which analyzes four key parameters in the propagation of Covid-19. We have named these parameters: A, B, C and D, by which: A: coefficient of viral acquisition, B: viral latency, C: coefficient of viral emission, D: constant of viral reproduction. These parameters are thus named A, B, C and D, whereby: Parameters: $\mathrm{A}, \mathrm{B}$ and $\mathrm{C}$ are associated with physiological parameters intrinsic to the individual. These include age, 
sex, height, body weight, glycemic levels, cholesterol levels, hemoglobin levels and glycated hemoglobin levels. Parameter $\mathrm{D}$ stands for the constant of Covid-19 viral reproduction.

The VTi in selected enclosed spaces (VTcs) was calculated according to the mathematical algorithm proposed by Prof. Luis CRUZ RODRIGUEZ [17].

Here we have proposed a Certificate called "Elidan certificate" denoting prolonged safety in enclosed areas such as inside buildings or with various modes of transportation, by proposing the acceptable number of people who may safely occupy those places at any given time [18].

\section{Methods and Materials}

To develop the objectives set forth, we propose the following working hypotheses:

If parameters: $\mathrm{A}, \mathrm{B}$ and $\mathrm{C}$ fall within the normal physiological range, then, viral transmission will fall to its lowest value, corresponding to the viral reproduction rate: $\mathrm{VTi}=\mathrm{D}$.

If parameters: $\mathrm{A}, \mathrm{B}$ and $\mathrm{C}$ fall outside the normal physiological range, then, viral transmission will reach the highest end of the value of the constant reproduction rate: $\mathrm{VTi}>\mathrm{D}$.

a) Individual Viral Transmission: VTi

The equation is defined by the following mathematical algorithm developed by Prof. Luis CRUZ RODRIGUEZ in collaboration with his colleague Lenier Sánchez Batista.

$$
V T_{i}=D\left[100001 e^{\left[\frac{(V-9841)^{2}}{8\left(10^{8}\right)}-100000\right]}\right.
$$

VTi Unit: San (The unit of measurement San has been assigned by Prof. Luis CRUZ RODRIGUEZ in acknowledgment of the collaboration by Lenier Sánchez Batista in the development of this algorithm.

\section{b) Data Vector: V}

$\mathrm{V}$, is composed by the vectorial arrangement of parameters $\mathrm{A}$, $\mathrm{B}, \mathrm{C}$. These parameters (Table 1) have been grouped in the vector $\mathrm{V}=[\mathrm{B} \mathrm{C} \mathrm{A}]$

\begin{tabular}{|l|l|l|l|l|l|l|l|l|}
\hline Parameters & Age & Hemoglobin $(\mathrm{Hb})$ & Sex & Glycated Hb & Cholesterol & Glycemia & Body Weight & Height \\
\hline A & $*$ & $*$ & $*$ & & & & & \\
\hline B & & & $*$ & $*$ & $*$ & $*$ & & \\
\hline C & & & & & $*$ & $*$ & $*$ & $*$ \\
\hline
\end{tabular}

Where:
$\mathrm{V}=[$
B
C
A ]
$\mathrm{V}=[$ (cholesterol, glycemia, Hb/glycated Hb) (glycemia, body weight, height) (age, Hb, sex) ]

The relationship among individuals respecting the coefficient of individual viral transmission of Covid-19 is shown in Figure 1 below.

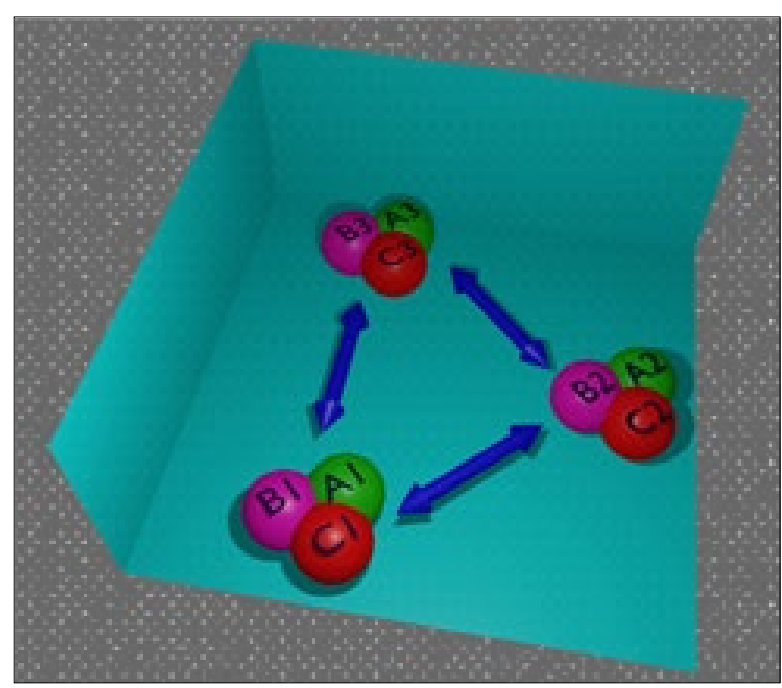

Figure 1: Schematic representation of Individual Viral Transmission (VTi) of Covid-19.

In creating the mathematical algorithm VTi, CRUZ RODRIGUEZ L. and SANCHEZ BATISTA L. utilized the inverse Gaussian distribution or inverted Gaussian bell curve adjusted to the objectives of this present work.

The graph (Figure 2) facilitates an interpretation of a physiological qualitative research of parameters A, B, C related to the viral transmission of Covid-19.

The equation is defined by the following mathematical function:

$$
f(x)=\boldsymbol{\alpha} e^{\frac{(x-b)^{2}}{2 C^{2}}}-d
$$

where $\alpha, b, c$ and $d$, are constants in the domain of real numbers, $(\mathrm{c}>-1)$.

$\alpha=D^{*} 100001, b=9841, c=4 * 104, d=D^{*} 100000, x$, Domine $(V)$

The subtraction between parameters $\alpha$ and $d(\alpha-d)$ is the "vortex" the lowest value VTi (value is D) in the inverted bellshaped graph. Constant $b$ is the center of the inverted bell in the $\mathrm{x}$ axis $(\mathrm{V}=9841)$ (Figure 2); while $\mathrm{c}\left(4^{*} 104\right)$ is the standard deviation that modulates the width of the bell. 


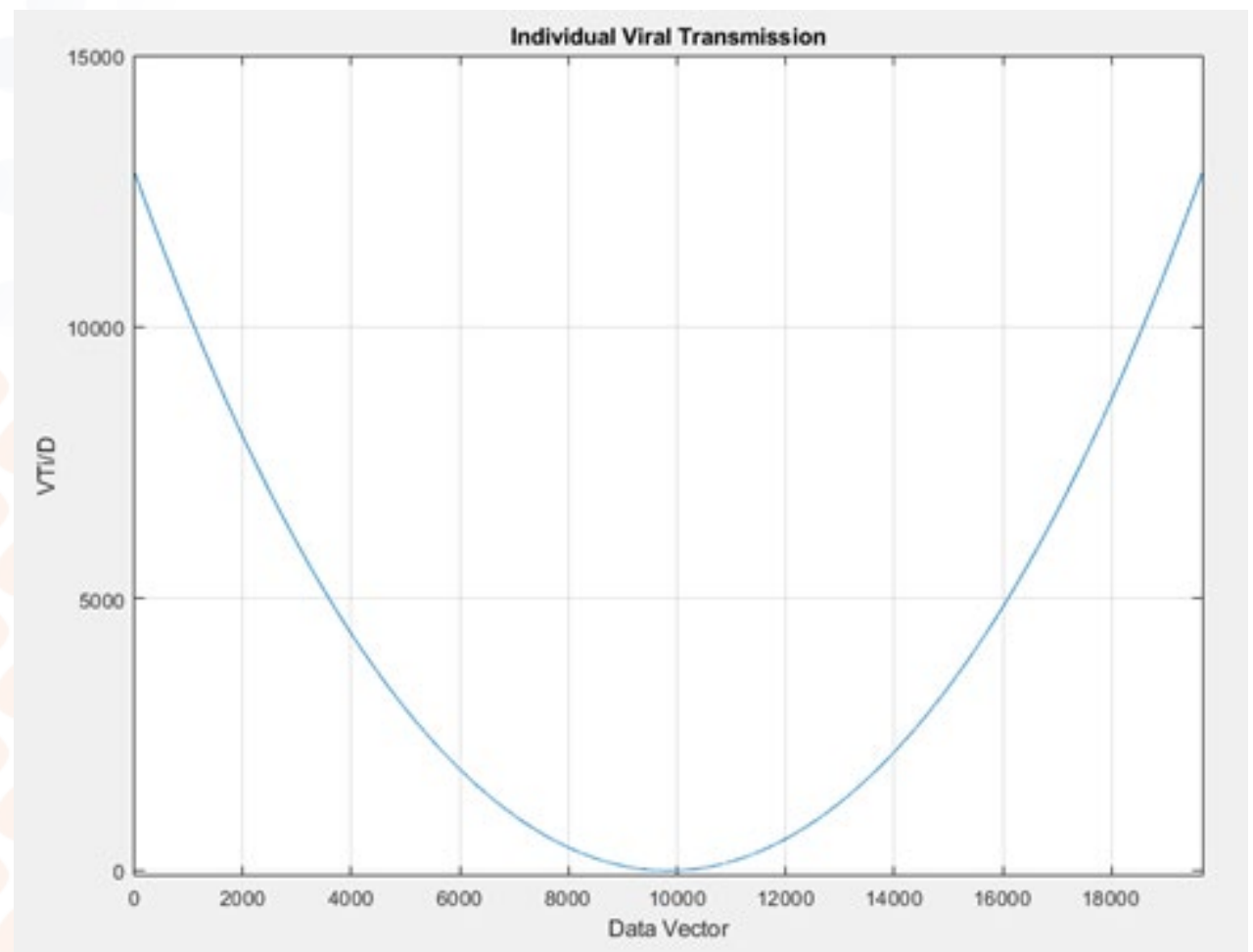

Figure 2: Represents the graph of the distribution of the Viral Transmission of Covid-19 from the Data Vector.

c) Closed Space Viral Transmission (VTcs)

Calculation of VTcs at random distances between individuals (fetuses, living individuals, deceased individuals) in a given enclosed space at a given temperature.

$$
V T_{c s}=\frac{T \Delta V T_{i}}{V o l}
$$

$\mathrm{VT}_{\text {cs unit }}:\left({ }^{\circ} \mathrm{C} / \mathrm{m} 3\right)$ San: Bat

VTcs Unit: Bat (The unit of measurement Bat has been assigned by Luis CRUZ RODRIGUEZ in acknowledgement of the collaboration of Lenier Sánchez Batista in the development of this algorithm.

Where:

VTes : Closed Space Viral Transmission

T : Corporal Temperature (Higher VTi) - Room Temperature $\left[{ }^{\circ} \mathrm{C}\right]$,

$\Delta \mathbf{V T i}=($ Higher VTi $)-($ Lower VTi $)$,

Vol : Closed Space Volume $\left[\mathrm{m}^{3}\right]$

In Figure 3 (below) the dependency of the viral transmission on the number of people in a given volume is shown in a schematic way.

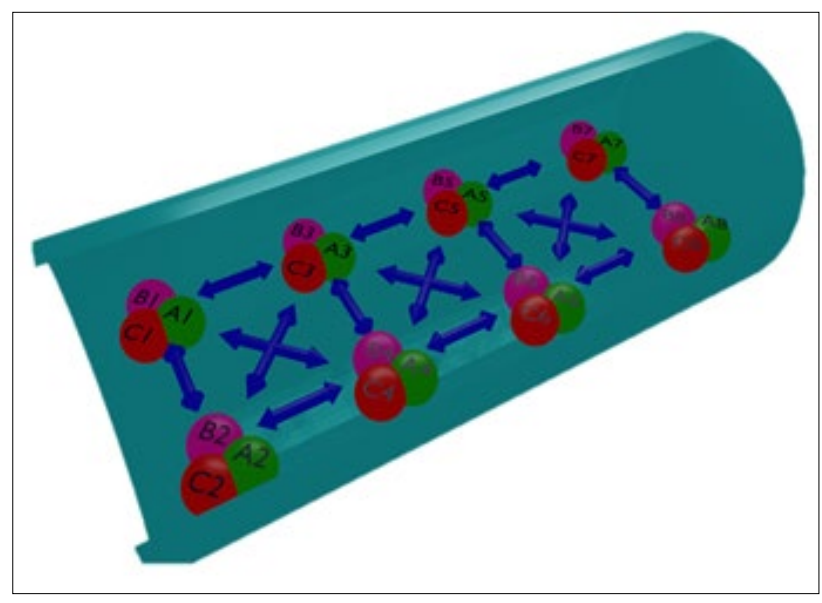

Figure 3: Schematic representation of Individual Viral Transmission (VTi) of Covid-19 in Closed Spaces (VTcs)

The enclosed spaces can be:

d) Modes of transportation:

Autos

Buses

Trains

Underground Metro*

Airplanes

Ships

e) Buildings:

Houses

Hotels

Restaurants

Hospitals 


\section{Schools}

Laboratories

Halls (Cinemas, theaters, churches, mosques...)

Factories/abattoirs

Mines

\section{Calculation of VTi and VTes:}

Codification of Parameters

The codification of the vector $\mathrm{V}$ (B C A) was made possible by the ternary code $(0 ; 1 ; 2)$

Where we defined that:

f) 0 : corresponds to the lowest value of the normal physiological range

g) 1: normal physiological range

h) 2: highest physiological range

*The variable age will only be codified in the ternary code $(0$; $1 ; 2$ ), corresponding to: (fetal individuals; living individuals; deceased individuals)

*The variable sex will only be codified in a simplified code (1; 2), corresponding to: (normal sex; hermaphrodite sex)

How to know the number of persons (NP) in safe condition in closed space?

According to 2 meters of security distance between persons:

a. Volume of security for one person is equal to $\mathrm{Vp}=(4 * 4 * 2)$ $\mathrm{m}^{3}$

b. Volume of security for one person is equal to $\mathrm{Vp}=* \mathrm{~m}^{3}$ (Patent in revision)

Where:

$\mathrm{NP}=[(\mathrm{Vt} / \mathrm{Vp})$

$\mathrm{Vt}$ : Volume total of closed space $(\mathrm{h}=2 \mathrm{~m})$

$\mathrm{Vp}$ : Volume of security for one person $32 \mathrm{~m}^{3}$

$\mathrm{Ab}$ : avaible base of the surface of the closed place

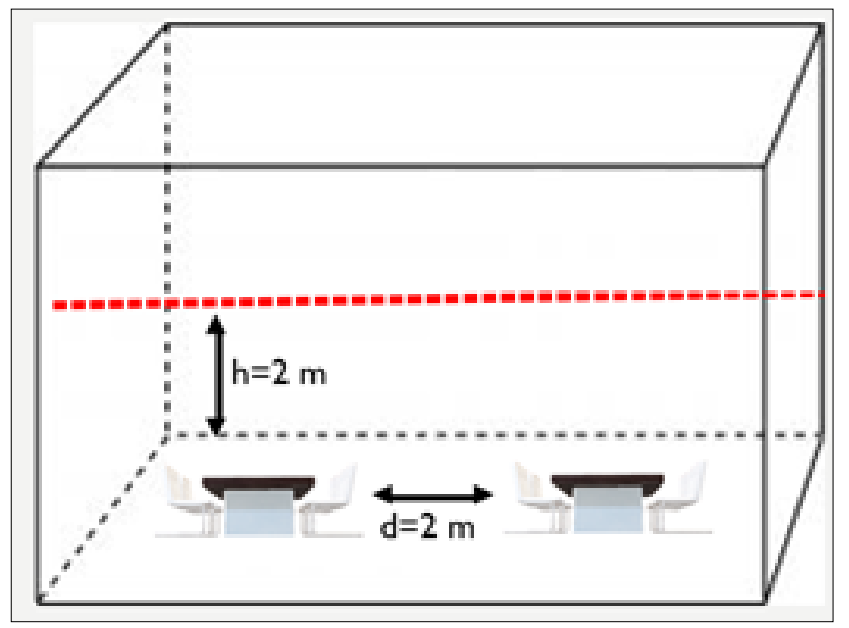

Figure 4: Schematic representation of volume of Covid-19 in Closed Spaces.

\section{Results and Discussion}

Analysis of extreme physiological situations for each individual in the codification of Viral Data (V) is as follows:

$\mathrm{V}=[\mathrm{B}$

$\mathrm{V}=[$ (cholesterol, glycemia, $\mathrm{Hb} /$ glycated $\mathrm{Hb}$ ) (glycemia body weight, height) (age, $\mathrm{Hb}, \mathrm{sex})]$

1. If the physiological values of: cholesterol, glycemia, $\mathrm{Hb} /$ glycated $\mathrm{Hb}$, glycemia, body weight, height, age, $\mathrm{Hb}$, and sex are below the normal physiological range

Then,

$\mathbf{V}=\left[\begin{array}{lllllllll}0 & 0 & 0 & 0 & 0 & 0 & 0 & 0 & 1\end{array}\right]$

The ternary notation becomes decimal, where:

$\mathbf{V}=1$

Substituting for the decimal value.

$$
\begin{gathered}
V T_{i}=D\left[100001 e^{\left[\frac{(1-9841)^{2}}{8\left(10^{8}\right)}\right]}-100000\right] \\
V T_{i}=1.2867\left(10^{4}\right) D
\end{gathered}
$$

2. If the physiological values of: cholesterol, glycemia, $\mathrm{Hb} /$ glycated $\mathrm{Hb}$, glycemia, body weight, height, age, $\mathrm{Hb}$, and sex fall within the normal physiological range

Then,

$$
\mathbf{V}=\left[\begin{array}{lllllllll}
1 & 1 & 1 & 1 & 1 & 1 & 1 & 1 & 1
\end{array}\right]
$$

changing from ternary to decimal notation, where: $\mathbf{V}=9841$

Substituting for the decimal value:

$$
\begin{gathered}
V T_{i}=D\left[100001 e^{\left[\frac{(V-9841)^{2}}{8\left(10^{8}\right)}\right]}-100000\right] \\
V T_{i}=D\left[100001 e^{\left[\frac{(9841-9841)^{2}}{8\left(10^{8}\right)}\right]}-10000\right. \\
V T_{i}=1 D
\end{gathered}
$$

3. If the physiological values of: cholesterol, glycemia, $\mathrm{Hb} /$ glycated $\mathrm{Hb}$, glycemia, body weight, height, age, $\mathrm{Hb}$, and sex go over and above the normal physiological range

Then,

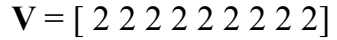

$$
\begin{aligned}
& \text { the ternary notation becoming decimal: } \\
& \mathbf{V}=19682 \text { combinations }
\end{aligned}
$$

Substituting for the decimal value:

$$
V T_{i}=D\left[100001 e^{\left[\frac{(V-9841)^{2}}{8\left(10^{8}\right)}\right]}-100000\right]
$$




$$
\begin{gathered}
V T_{i}=D\left[100001 e^{\left[\frac{(19682-9841)^{2}}{8\left(10^{8}\right)}\right]}-100000\right] \\
V T_{i}=1.2870\left(10^{4}\right) D
\end{gathered}
$$

\section{Conclusions}

Utilizing VTi standards, and no matter whether the movement of people in open spaces is free or restricted, viral transmission can be predicted.

Fetuses present a coefficient of viral transmission of Covid-19 lower than that of living beings.

The CoVs have become the major pathogens of emerging respiratory disease outbreaks. They are a large family of single-stranded RNA viruses (+ssRNA) that can be isolated in different animal species. For reasons yet to be explained, these viruses can cross species barriers and can cause, in humans, illness ranging from the common cold to more severe diseases such as MERS and SARS. Interestingly, these latter viruses have probably originated from bats and then moving into other mammalian hosts - the Himalayan palm civet for SARS-CoV, and the dromedary camel for MERS-CoV — before jumping to humans.

Utilizing VTes standards, the prolonged safety of individuals in a given enclosed space such as within buildings or inside various modes of transportation can be successfully predicted. The dynamics of SARS-Cov-2 are currently unknown, but there is speculation that it also has an animal origin. The potential for these viruses to grow to become a pandemic worldwide represents a serious public health risk. Concerning COVID-19, the WHO raised the threat to the $\mathrm{CoV}$ epidemic to the "very high" level, on February 28, 2020. Deceased individuals present a coefficient of viral transmission of Covid-19 higher than that of living individuals and fetuses.

By utilizing NP calculations for closed spaces, we can determine the most favorable conditions in order to reduce the risk of virus transmission.

\section{Economic Perspectives}

Having the ability and gratification of issuing safety certificates which validate the prolonged safety of individuals who occupy various enclosed spaces will allow for an improved control of the viral transmission of Covid-19.

Aerosol gases may be colloidal or complexes; when combined with humidity and temperature this can be problematic. Similar issues may exist in abattoirs for example. In both Australian and Canadian mining environments, isolation together with "fly-in-fly-out" mining procedures (considered normal in these remote locations) have experienced seriously disrupted productivity due to Covid-19. Should outbreaks occur in mining regions, closures have immediate economic implications for the country's payments schedule and overall economy.

Australia, Canada and South Africa are just a few examples where economies rely heavily on mining. Australia finds itself in a financial recession for the first time in 30 years, although in spite of its reliance on mining, it has been one of the best performers in the OECD during the Covid-19 pandemic. The country which had seen a mere 100 Covid-19 related deaths may be at risk for a more serious second wave or outbreak. If that happens, the consequences for this country will be catastrophic, and likewise for other countries where mining brings in a huge revenue.

In the wake of pandemics, financial recession is the norm, so having a better management of the situation is critical. Modelling and understanding the key factors involved with the transmission of this virus may therefore have important consequences, leading to positive social and economic impacts. In economies which are so heavily reliant on the mining industry, (South and North America, Australia, Canada, Africa, China, Russia and Iran,), it's critical for these countries to help keep their economies afloat. In such cases, together with other countries' unique situations, whereby people are residing in or occupying closed spaces, a proper safety certification will most likely yield positive outcomes with regard to national economics. When countries can simply avoid a shut-down or a lock-down due to health risks, economies stabilize.

The same theory applies to beneficiation and factories including agricultural facilities such as slaughterhouses, whereby work is performed in an enclosed space. The action of safety certification may translate into a better life for societies since viral epidemics and their frequency will most certainly be more regular in the future. Moreover, the current epidemic persists, evidenced by more serious second waves with the global infection rate climbing, indeed unabated.

With ever more persistent episodic viral pandemics coming and with respect to the current Covid-19 pandemic, what is at stake for the world economy are its basic pyramidal legs; its raw materials, without which the anthropocene grinds to a halt.

\section{Review: Perspectives}

On March 11, as the number of Covid-19 cases outside China has increased 13 times and the number of countries involved has tripled with more than 118,000 cases in 114 countries and over 4,000 deaths, WHO declared the Covid-19 a pandemic. World governments are at work to establish countermeasures to stem the devastating effects and it has been estimated that strict shutdowns may have saved 3 million lives across 11 European countries.

Health organizations coordinate information flows and issues directives and guidelines to best mitigate the impact of the threat. At the same time, scientists around the world work 
tirelessly, and information about the transmission mechanisms, the clinical spectrum of disease, new diagnostics, and prevention and therapeutic strategies are rapidly developing. Many uncertainties remain with regard to both the virus-host interaction and the evolution of the pandemic, with specific reference to the times when it will reach its peak. At the moment, the therapeutic strategies to deal with the infection are only supportive, and prevention aimed at reducing transmission in the community is our best weapon.

Aggressive isolation measures in China have led to a progressive reduction of cases. From China, the disease spread to Europe. In Italy, in geographic regions of the north, initially, and subsequently throughout the peninsula, political and health authorities have made incredible efforts to contain a shock wave that has severely tested the health system. Based on the existing evidence, it is possible to prevent the transmission of Covid-19 through the proper use of UV technology.

The International Ultraviolet Association (IUVA) is a non-profit organization focused on the development and advancement of UV technologies to help tackle microbiological threats as a matter of public health and the environment.

This association, through a document published on its official website, maintains that, based on current disinfection data and empirical evidence, UVC disinfection technologies can play an important role in the multiple barriers applied to reduce the transmission of the causative virus del Covid-19, SARS-Co-2. In this regard, UVC is a well-known disinfectant for air, water and surfaces, which can help reduce the risk of acquiring Covid-19 when applied correctly. By the way, the IUVA has been given the task of bringing together a group of experts, leaders in the field, from various parts of the world with the aim of developing guides that contribute to an effective use of UVC Technologies (ELIDAN dynamic LLC).

UV light has been extensively used for more than 40 years in the disinfection of water, wastewater, pharmaceuticals, surfaces and rooms [19]. And although all bacteria and viruses examined to date (hundreds of them for years, including other types of coronaviruses) respond to UVC light, some are nevertheless more susceptible than others to UVC disinfection, so in specific cases these they must be inactivated with the appropriate doses of radiation.

Also, UVC disinfection is often used as a complementary mechanism to other technologies to ensure that any pathogen that has not been inactivated by some previous method (filtration or cleaning) is finally removed with UVC. In this way, UVC light could be installed in clinics as an additional method to existing processes and protocols, which - otherwise - could be wearing out given the unique demand for UVC technology caused by the pandemic.

The validation of safety while working inside of mines (where there is minimal temperature control) raises another issue; that of ventilation control. It is known that gaseous minerals can potentiate the propagation of aerosols, and therefore, a control of the mining process could be favorable in reducing the viral transmission of Covid-19. For instance, it is known that the temperature and humidity factor is highly related to ventilation within the mining environment. In fact, the third mode of Covid-19 infection is by way of aerosols, which do not settle out; viral laden droplets to the ground are persistent and essentially permanently airborne in closed spaces.

It is worth noting that UVC light, specifically between 200$280 \mathrm{~nm}$ [20], inactivates two other coronaviruses that are close to the Covid-19 virus (these are SARS-CoV [21] and MERS$\mathrm{CoV}$ [22]). It is important to demonstrate that an inactivation has previously been performed under controlled laboratory conditions, since the effectiveness of UVC light in practice depends on factors such as the exposure time, and the ability of UVC light to be absorbed by viruses in water, air, and the folds and crevices of existing materials and surfaces.

Covid-19 infection can occur through contact with contaminated surfaces and then bring the hands to the face (less common than person-to-person transmission, but in considerable amounts) [24-25]. In such a case, minimizing the risk of contagion by contact is key, since Covid-19 can live on plastic and steel surfaces for up to three days [26]. Traditional cleaning could leave residues of microbiological contamination, which can be removed with UVC, suggesting that an optimal measure is to apply multiple disinfecting methods.

The IUVA agrees with the CDC (Center for Disease Control and Prevention) Guidelines for Hospitals that the effectiveness of UVC depends on how UV light is absorbed, on suspendedparticles or on surfaces that contain the microbiological threat. It also depends on the spectrum of action of the microorganism, the variety of device designs, and operational factors that impact the applied dose [27].

Some devices also produce ozone as part of their process, while others produce light and heat as the electric arc from the weld. Therefore, the safety of both the user and the equipment should be considered in all UVC technology applications, and these considerations should be detailed in the user manual, taught in operator training, and included in the statements of confidence and security.

This type of mechanism produces a variety of UVC light between 200 and $280 \mathrm{~nm}$, "stronger" than sunlight, so it can cause severe damage to the skin and also damage the retina of the eyes if they are exposed.

\section{Acknowledgements}

The authors recognize the infrastructure, and the support of "ELIDAN DYNAMIC LLC/USA, ExCELab Co. Ltd/Jamaica, and ELIDAN genome SAS/France", Institutes.

\section{Conflict of interest}

All authors declare no conflict of interest. 
ORCID identification

CRUZ-RODRIGUEZ L. : https://orcid.org/0000-00027539-2382.

BEN HADDA T. : https://orcid.org/0000-0002-56336203.

ALMALKI F. A.: https://orcid.org/0000-0003-40481526.

WARAD I. : http://orcid.org/ 0000-0001-8853-8961

References

1. Cascella M, Rajnik M, Cuomo A, Dulebohn SC, Di Napoli R (2020)'Features, Evaluation and Treatment Coronavirus (COVID-19)", SourceStatPearls [Internet]. Treasure Island (FL): StatPearls Publishing; 2020

2. Zhou P, Yang XL, Wang XG, Hu B, Zhang L, Zhang W, Si HR, Zhu Y, Li B, Huang CL, et al. (2020) "A pneumonia outbreak associated with a new coronavirus of probable bat origin". Nature, 579: 270-273.

3. Gralinski LE, Menachery VD (2020) "Return of the Coronavirus: 2019-nCoV". Viruses 12(2): 135.

4. CRUZ-RODRIGUEZ L., DILSIZ N., ZIARATI P., LAMBERT BROWN D., HOCHWIMMER B., ZAYAS TAMAYO AM., SANCHEZ BATISTA L., MORADI M (2020) "A miRNA-PEPTIDE FUSION AS A VACCINE CANDIDATE AGAINST THE NOVEL CORONAVIRUS (COVID-19). EXOSOMES AS POTENTIAL BIOMARKERS OF SARS-COV-2 IN LUNG: AFTER AND BEFORE VACCINATION LCR_2020_B008-13" International Journal of Infectious Diseases and Research, I J Infectious Disea; 2020. https://unisciencepub.com/wpcontent/uploads/2020/05/A-miRNA-PEPTIDE-FUSIONAS-A-VACCINE-CANDIDATE-AGAINST.pdf

5. Wang Z (2020) "A Handbook of 2019-nCoV Pneumonia Control and Prevention", Hubei Science and Technology Press. January 2020.

6. Zhu N, Zhang D, Wang W, Li X, Yang B, Song J, Zhao X, Huang B, Shi W, Lu R, Niu P, Zhan F, Ma X, Wang D, Xu W, Wu G, Gao GF, Tan W (2020)“A Novel Coronavirus from Patients with Pneumonia in China, 2019." N Engl J Med 382(8): 727-733. doi: 10.1056/NEJMoa2001017.

7. Centeno JA, Finkelman RB, Selinus O (2016) "Medical Geology: Impacts of the Natural. Environment on Public Health": Geosciences 2016, 6, 8; doi:10.3390/geosciences 6010008.

8. Selinus O, Alloway B, Centeno JA, Finkelman RB, Fuge R, Lindh U, Smedley P (Editors) (2005) "Essentials of Medical Geology". Elsevier, Amsterdam, 820 p. (second edition published by Springer 2012).

9. Selinu O, Finkelman B, Centeno JA (2009) Editors." Medical Geology - a regional synthesis”. Springer. 2010.

10. Hochwimmer B, Cruz-Rodriguez L (2005) “The Polygonal Vortex Mineralisation Model: a predictive tool of health indices and the proposed use of such "geologically based public health indices as a sub discipline of Medical Geology”. 2005, ISBN 9697117037.

11. Cruz-Rodriguez L, Hochwimmer B, Selinus O (2005) "Medical Geology in Cuba". 2005, ISBN 9697117037.
12. Hochwimmer B, Ziarati P, Selinus O, Elwej A, Lambert Brown D, Zayas Tamayo AM, Moradi M, Cruz-Rodriguez L (2020) "A predictive geological tool of Type3 Diabetes (Alzheimer's disease): The Polygonal Vortex Mineralisation Model a Medical Geology perspective"; Journal of Diabetes and Endocrinology Research 2020 April, 2020 Volume 2, Issue 2. https://unisciencepub.com/ wp-content/uploads/2020/04/A-Predictive-GeologicalTool-of-Type-3-Diabetes-The-Polygonal-Vor.pdf

13. CRUZ-RODRIGUEZ L, ZAYAS TAMAYO AM, SANCHEZ BATISTA L, LAMBERT BROWN D, HOCHWIMMER B, ZIARATI P (2020) “A Novel vaccine candidate with double antiviral activity against the HIV1 and Covid-19": International Journal of Infectious Diseases and Research,I J Infectious Disea; 2020. https:// unisciencepub.com/wp-content/uploads/2020/05/ANovel-Vaccine-Candidate-with-Double-AntiviralActivity-against-the-Hiv-1-and-Covid-19.pdf

14. CRUZ-RODRIGUEZ L, CRUZ-RODRIGUEZ LD, SANCHEZ BATISTA L, HOCHWIMMER B (2020) :'Calculation of Fusion Stability of [DNA or RNA] Peptide (FS) Algorithm "Cruz-Rodriguez" J B \& Bio Engine; 2020, vol 2, issue 1. https://unisciencepub.com/ wp-content/uploads/2020/05/CALCULATION-OFFUSION-STABILITY-OF-DNA-OR-RNA-PEPTIDEFS-ALGORITHM-CRUZ-RODRIGUEZ.pdf

15. CRUZ-RODRIGUEZ L, LAMBERT BROWN D, HOCHWIMMER B, SELINUS O, CRUZ-RODRIGUEZ LD, CRUZ-RODRIGUEZ ME, ZAYAS TAMAYO AM, SANCHEZ BATISTA L (2020) "A RNA-Peptide fusion as a vaccine candidate against the novel Coronavirus (COVID-19)"; Journal of Diabetes and Endocrinology Research 2020 April 2nd, 2020: J Diabetes Endocrinol Res; 2020: vol 2 issue 1. https://unisciencepub.com/wpcontent/uploads/2020/04/A-miRNA-PEPTIDE-FUSIONAS-A-VACCINE-CANDIDATE-AGAINST-THENOVEL-CORONAVIRUS-COVID-19.pdf

16. Kucharski AJ, Timothy W Russell, Charlie Diamond, Yang Liu, John Edmunds, Sebastian Funk, Rosalind M Eggo (2020) "Early Dynamics of Transmission and Control of COVID-19: A Mathematical Modelling Study", Lancet Infect Dis 20(5): 553-558. doi: 10.1016/ S1473-3099(20)30144-4. Epub 2020 Mar 11.

17. CRUZ-RODRIGUEZ L, SANCHEZ BATISTA L, HOCHWIMMER B, TAIBI BEN HADDA, ALMALKI F.A., DILSIZ N., CAPARROS J.L., LAMBERT BROWN D., ZIARATI P., ZAYAS TAMAYO A.M., PELAEZ FIGUEROA Y., HERRERA SANCHEZ M.B., GARCIA HERNANDEZ A., BIN ZHAO (2020)"How to Evaluate Viral Transmission in Enclosed Areas. Medical Geology saving places from Covid-19" Journal of Bioscience \& Biomedical Engineering; 2020, vol 1, issue 1. https:// unisciencepub.com/wp-content/uploads/2020/06/Howto-Evaluate-Viral-Transmission-in-Enclosed-Areas.Medical-Geology-saving-places-from-Covid-19.pdf

18. Jinming Cao, Xia Jiang, Bin Zhao (2020)"On the Human Infectious Disease Covid-19 Protective Clothing" International Journal of Infectious Diseases and Research Volume 1: Issue 1, 2020. 
19. Fluence (UV Dose) Required to Achieve Incremental Log Inactivation of Bacteria, Protozoa, Viruses and Algae "Miscellaneous Inactivating Agents - Guideline for Disinfection and Sterilization in Healthcare Facilities (2008);"

20. Centers for Disease Control and Prevention, National Center for Emerging and Zoonotic Infectious Diseases (NCEZID), Division of Healthcare Quality Promotion (DHQP)

21. Tsunetsugu-Yokota Y, et al. (2008) "Large-scale preparation of UV-inactivated SARS coronavirus virions for vaccine antigen," Methods Mol Biol. 2008; 454: 11926. doi: 10.1007 / 978-1-59745-181-9_11.

22. Bedell K et al. (2016)“Efficacy of an Automated Multiple Emitter Whole-Room Ultraviolet-C Disinfection System Against Coronaviruses MHV and MERS-CoV," ICHE 2016 May; 37 (5): 598-9. doi: 10.1017 / ice.2015.348. Epub 2016 Jan 28.

23. William A. Rutala, CIC, David J. Weber (2020)" Focus on Surface Disinfection When Fighting COVID-19 “; Infection Control Today, March 20, 2020

24. "Preventing the Spread of Coronavirus Disease 2019 in Homes and Residential Communities "; National Center for Immunization and Respiratory Diseases (NCIRD), Div. Of Viral Diseases

25. Zhaoxuan Wang, Zhiyu Yu, Changlin Tian, CruzRodriguez L, Sanchez Batista L and Bin ZHAO. "Differential equation analysis on COVID-19" 2020. Journal : Clinical Research and Clinical Trials Volume 2, Issue 1. https://www.auctoresonline.org/images/ currentissue/1595488878Differential_equation_analysis_ on_COVID.pdf

26. “ New coronavirus stable for hours on surfaces "; CDC (extracted from $\mathrm{N}$ van Doremalen, et al. Aerosol and surface stability of HCoV-19 (SARS-CoV-2) compared to SARS-CoV-1. The New England Journal of Medicine. DOI: 10.1056 / NEJMc2004973 (2020)

27. Kariwa H, Fujii N, Takashima I (2006) "Inactivation of SARS coronavirus by means of povidone-iodine, physical conditions and chemical reagents;" Dermatology 2006; 212 (Suppl 1): 119 Disinfection and Sterilization. 
ANNEXES

\section{$\underline{\text { Annexe } 01}$}

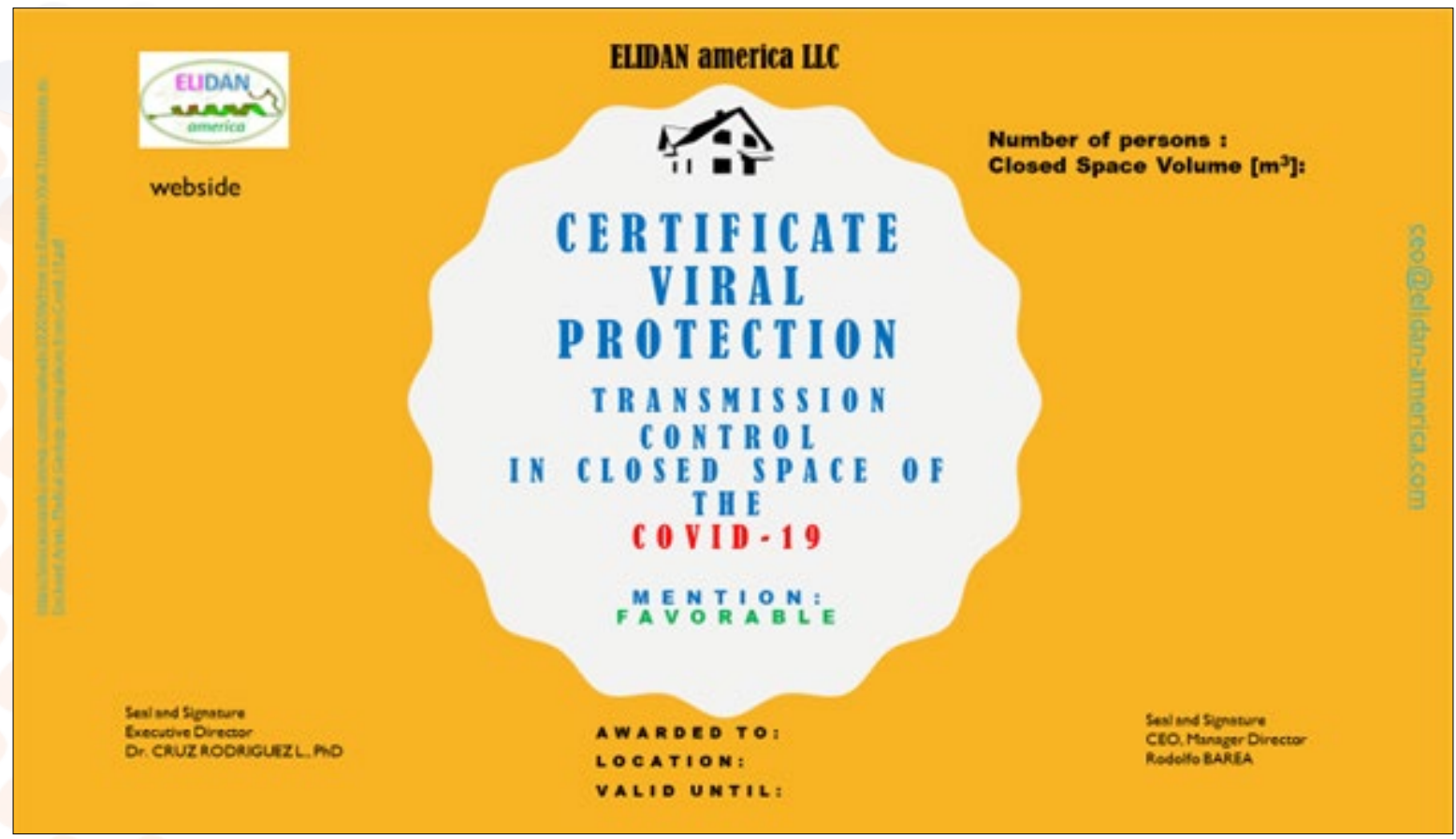

Annexe 02

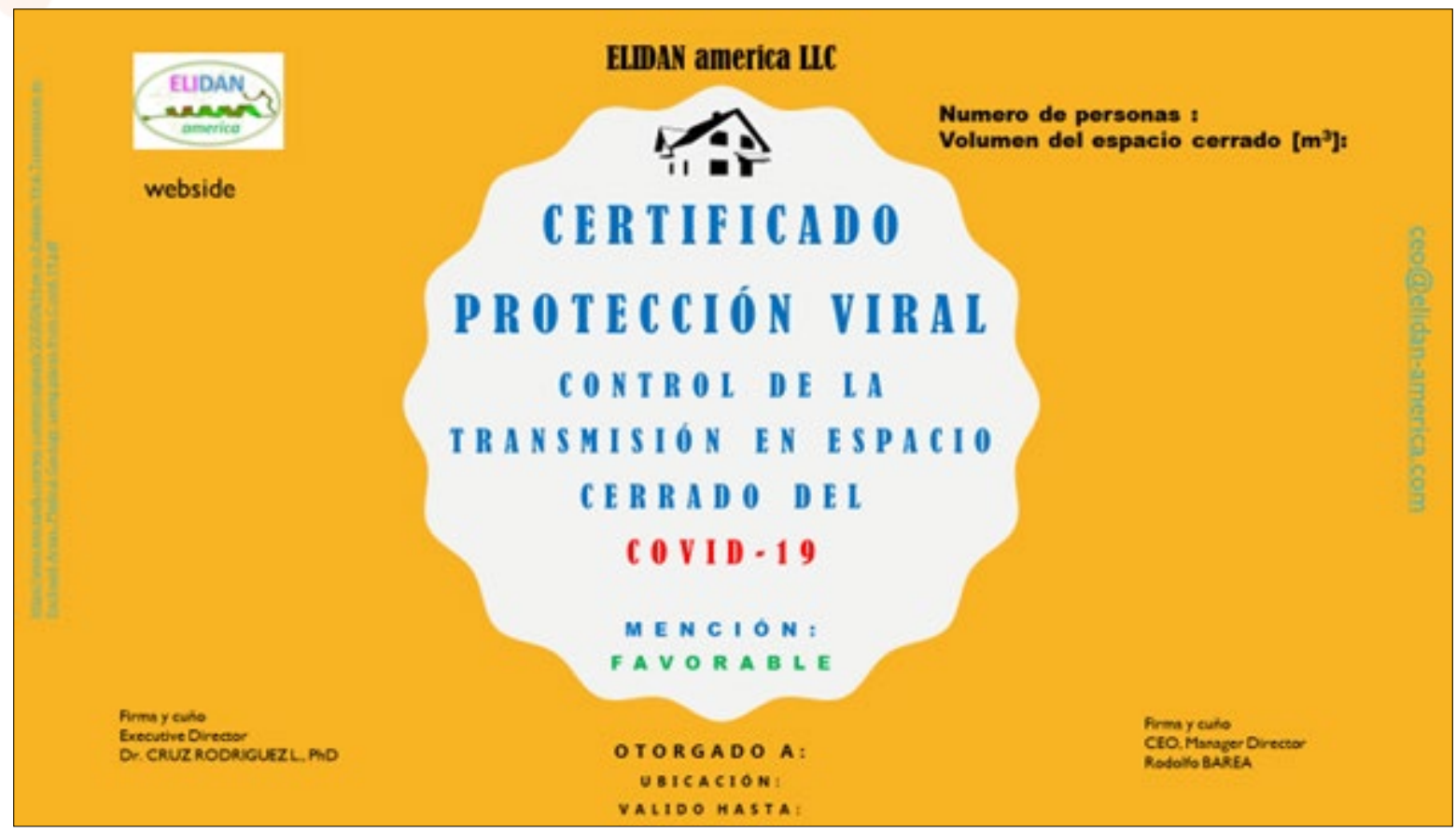




\section{Annexe 03}

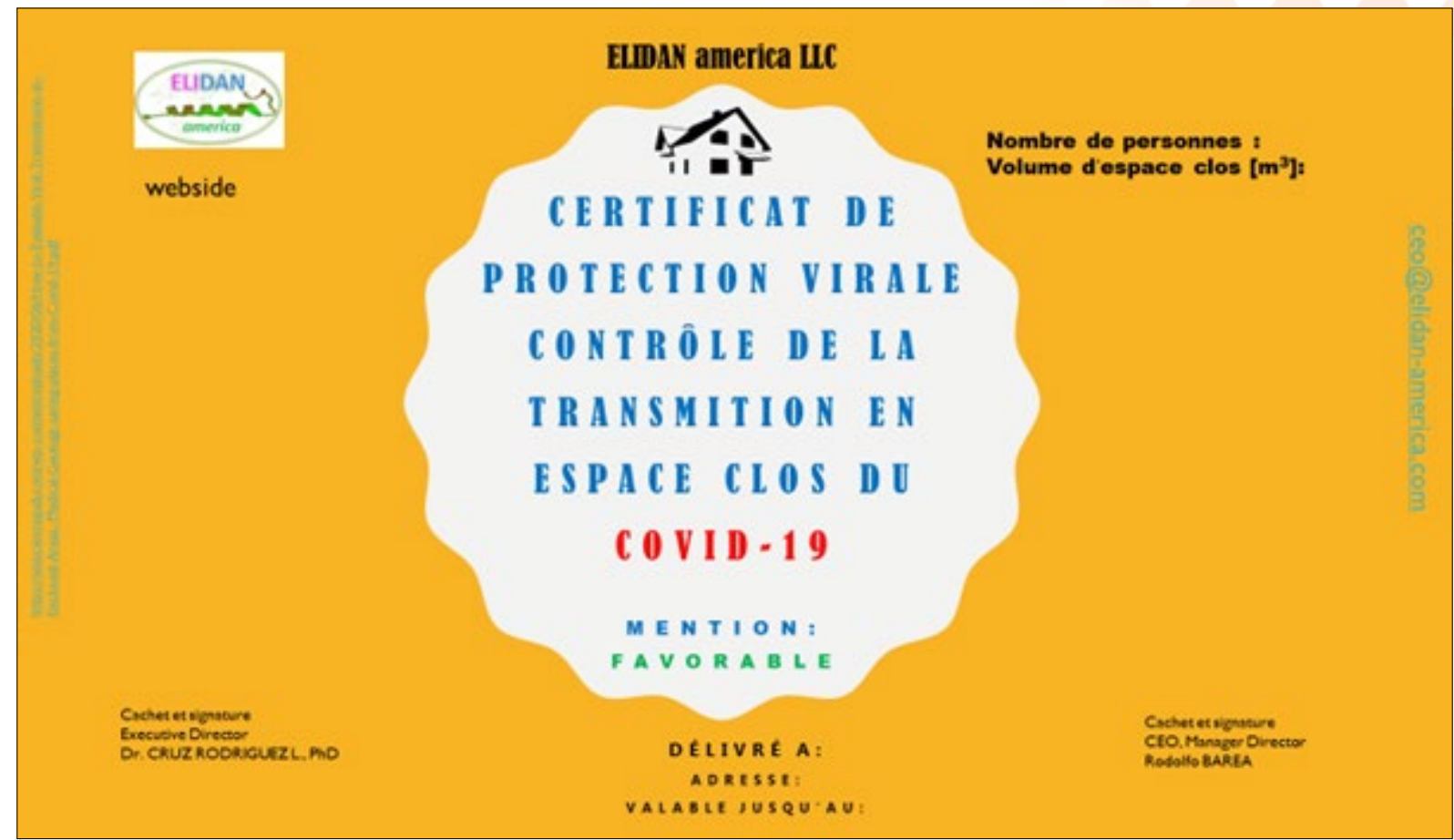

\section{$\underline{\text { Annexe 04 }}$}

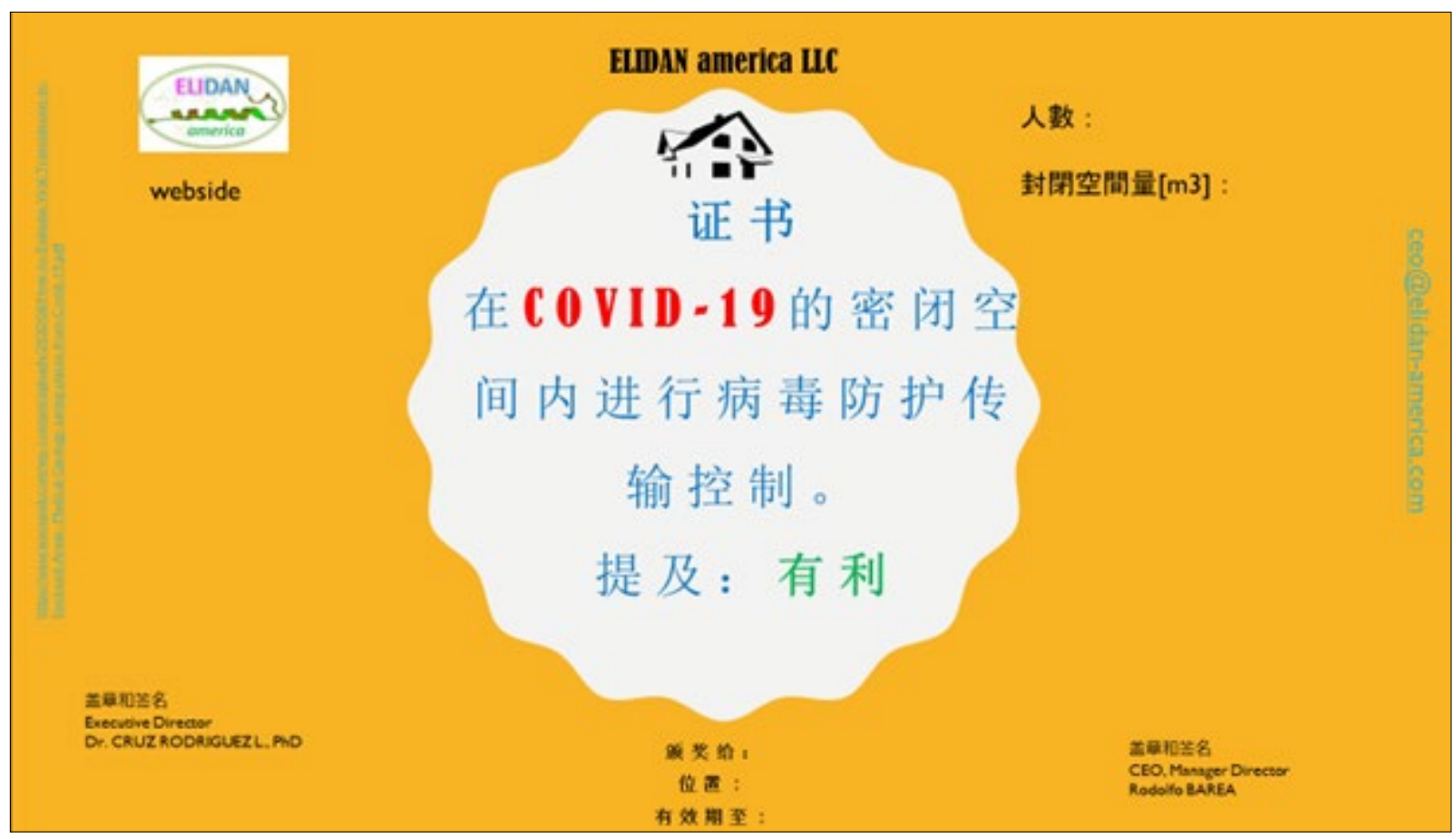




\section{Annexe 05}

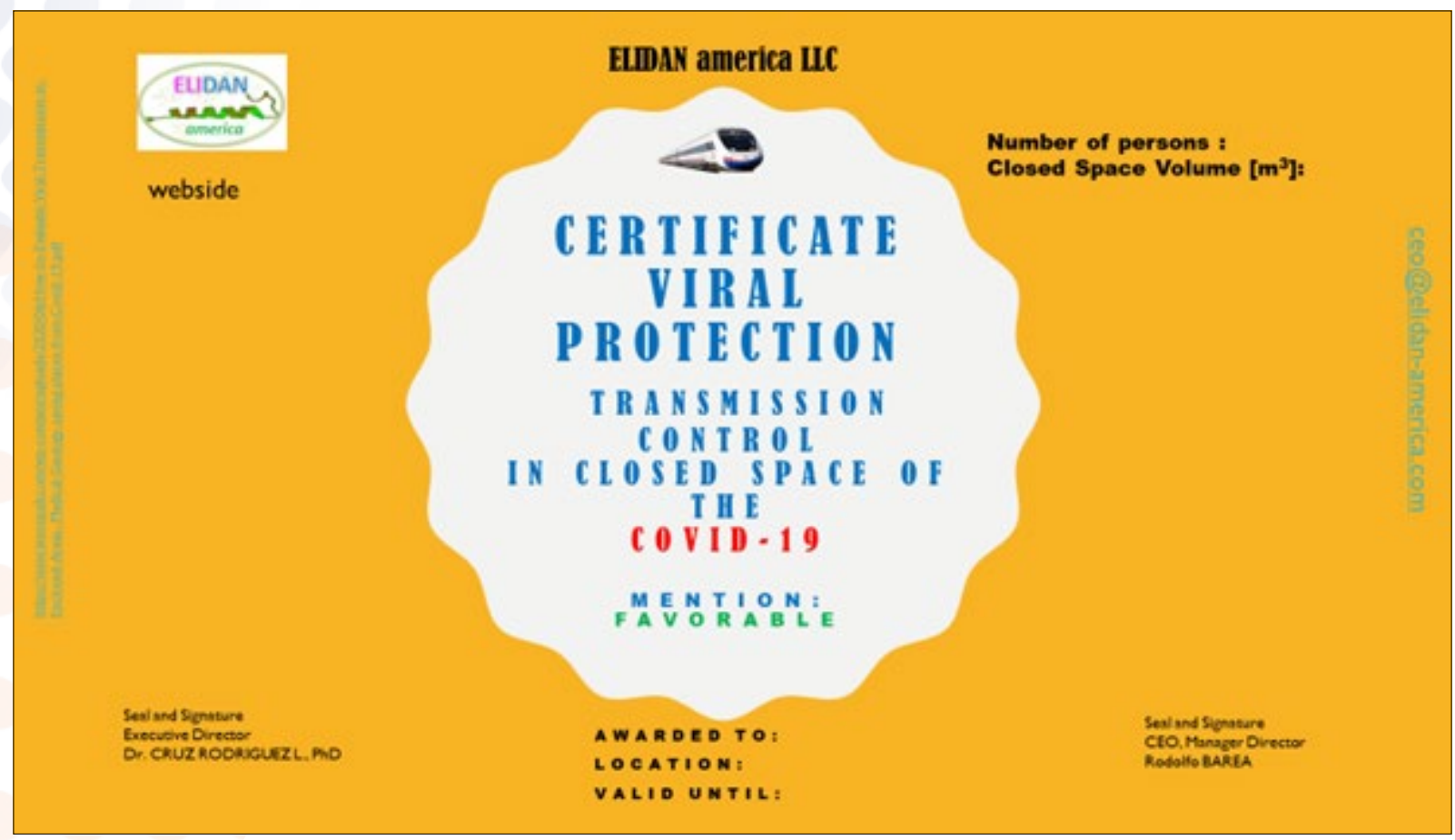

$\underline{\text { Annexe } 06}$

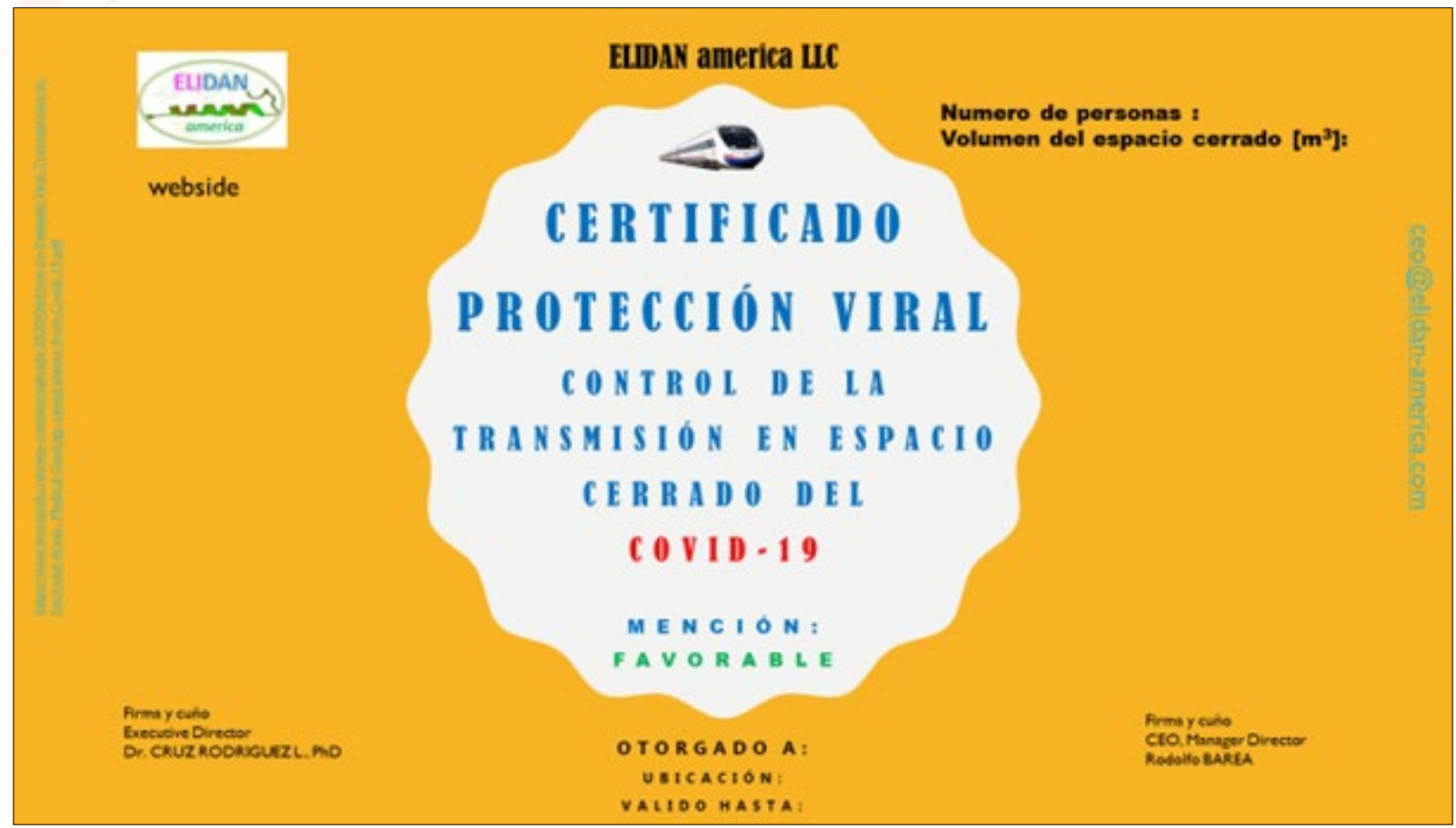




\section{Annexe 07}

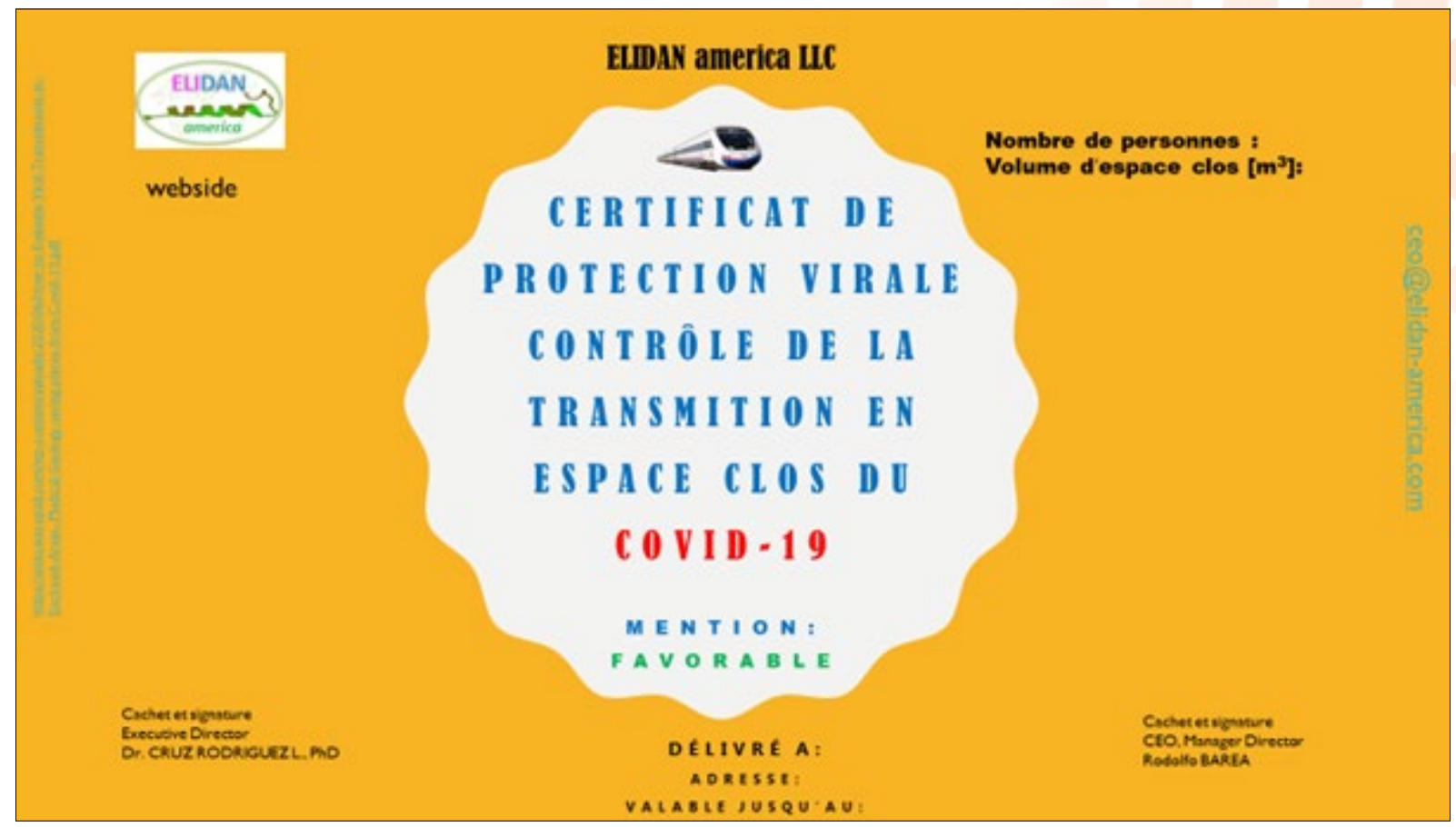

\section{$\underline{\text { Annexe } 08}$}

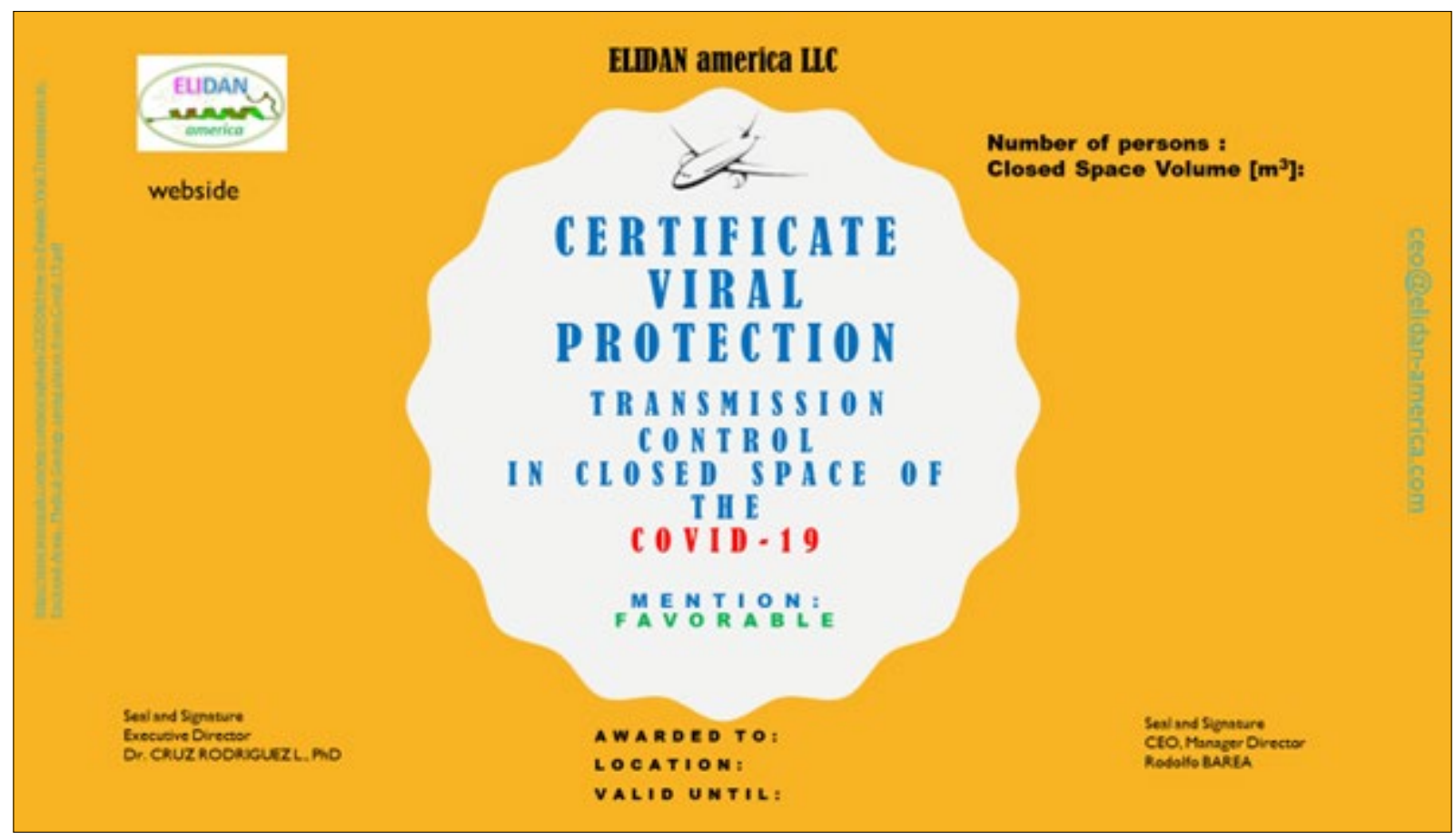




\section{Annexe 09}

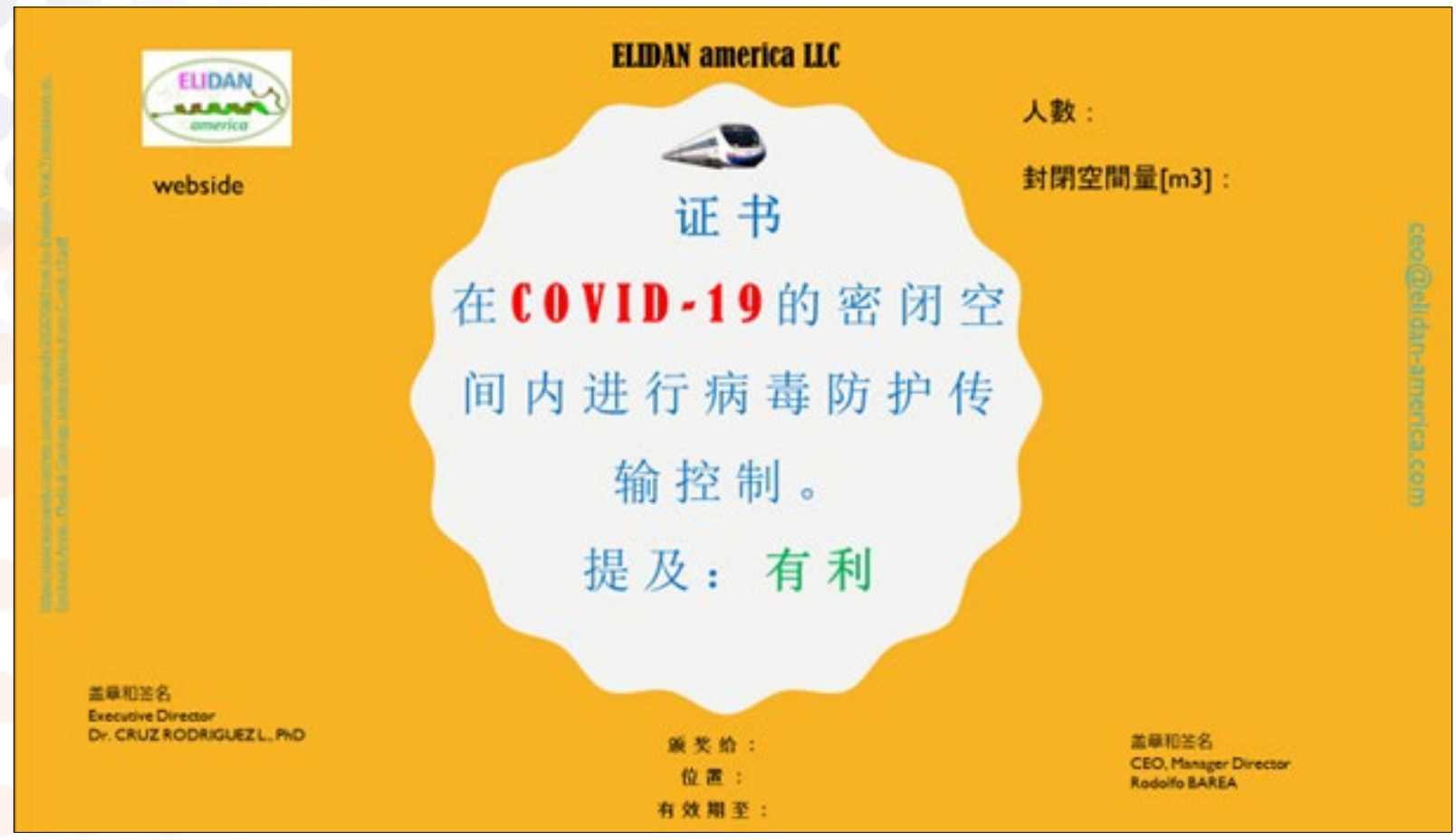

Annexe 10

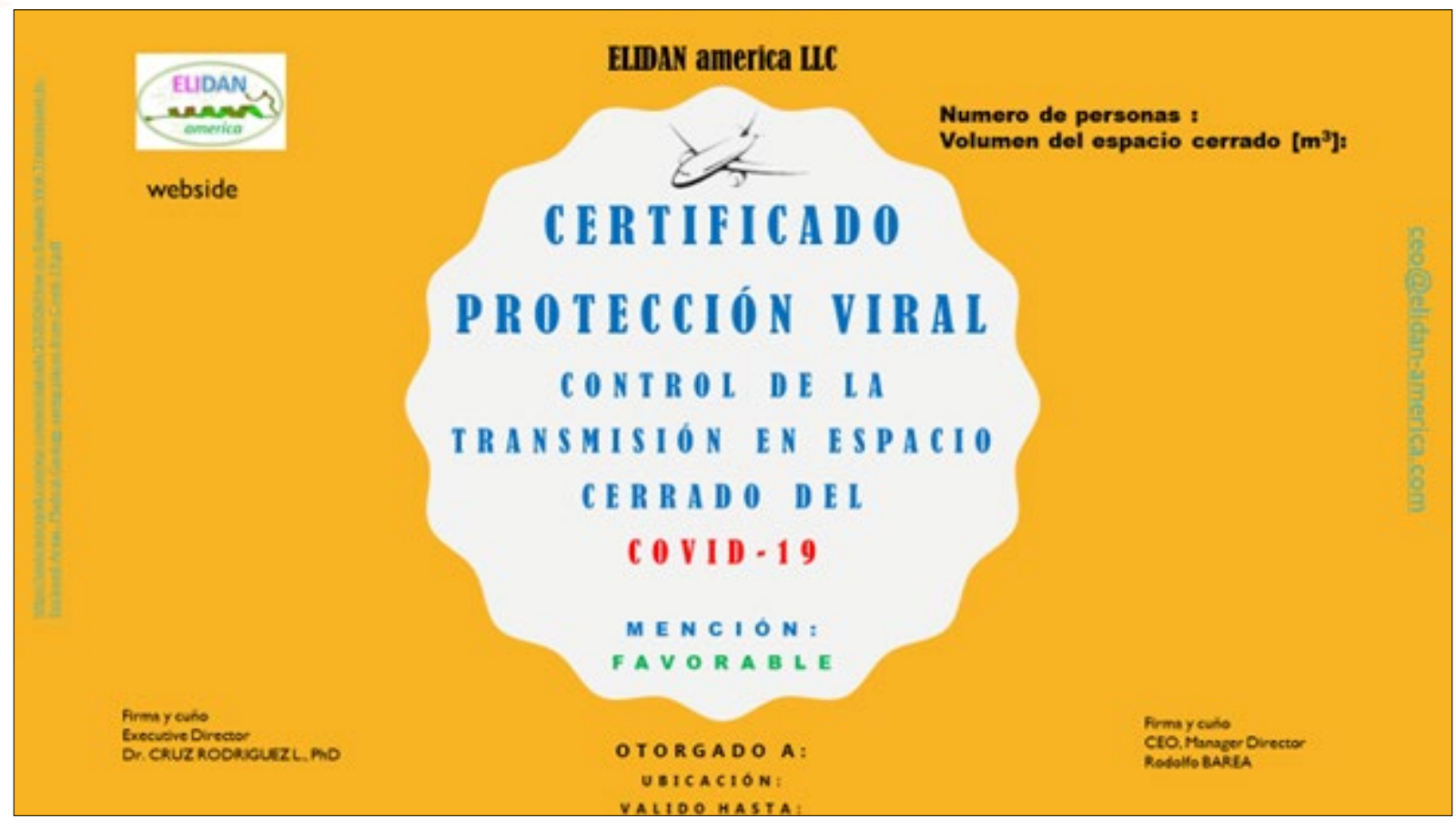




\section{Annexe 11}

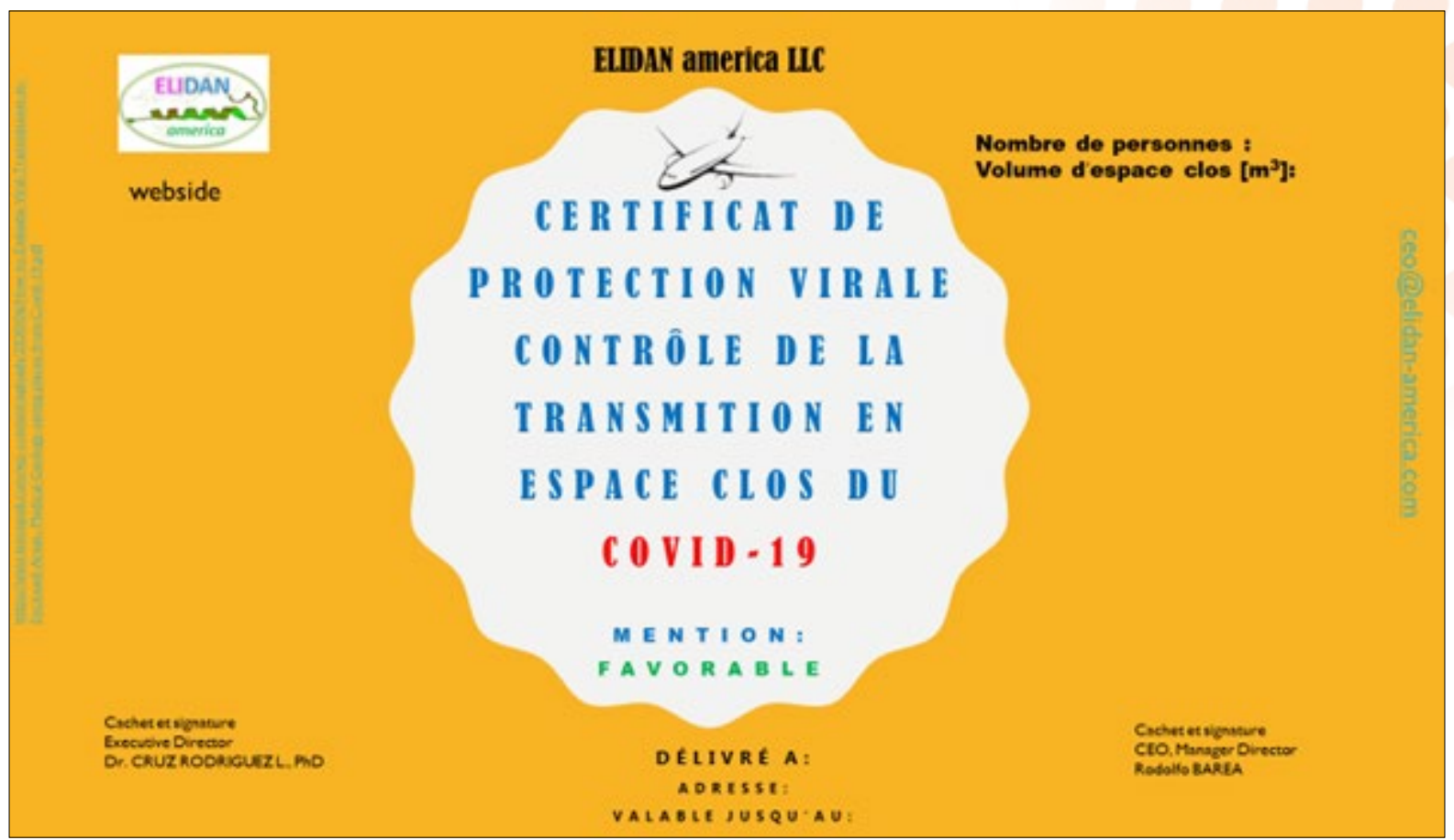

Annexe 12

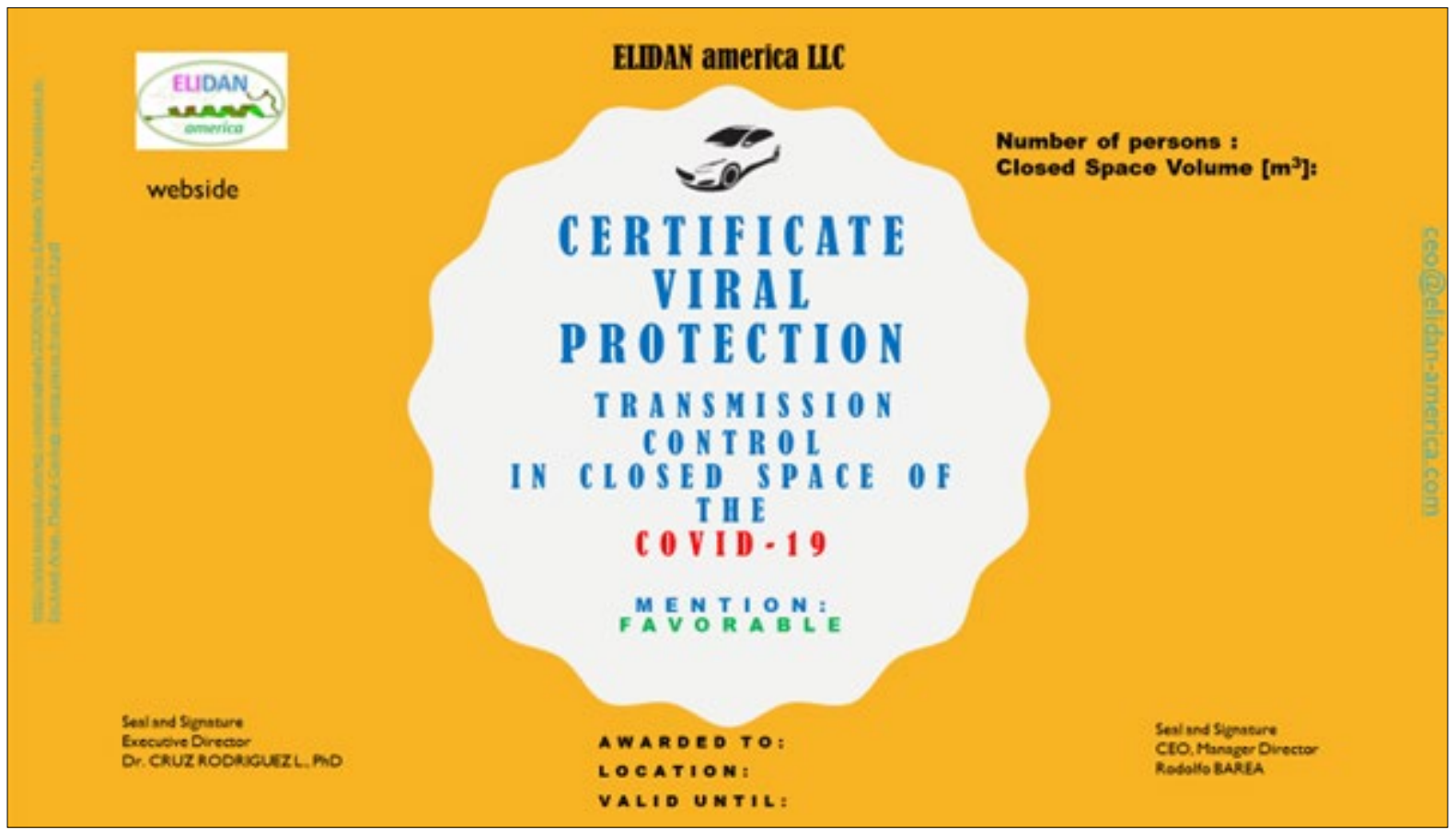




\section{Annexe 13}

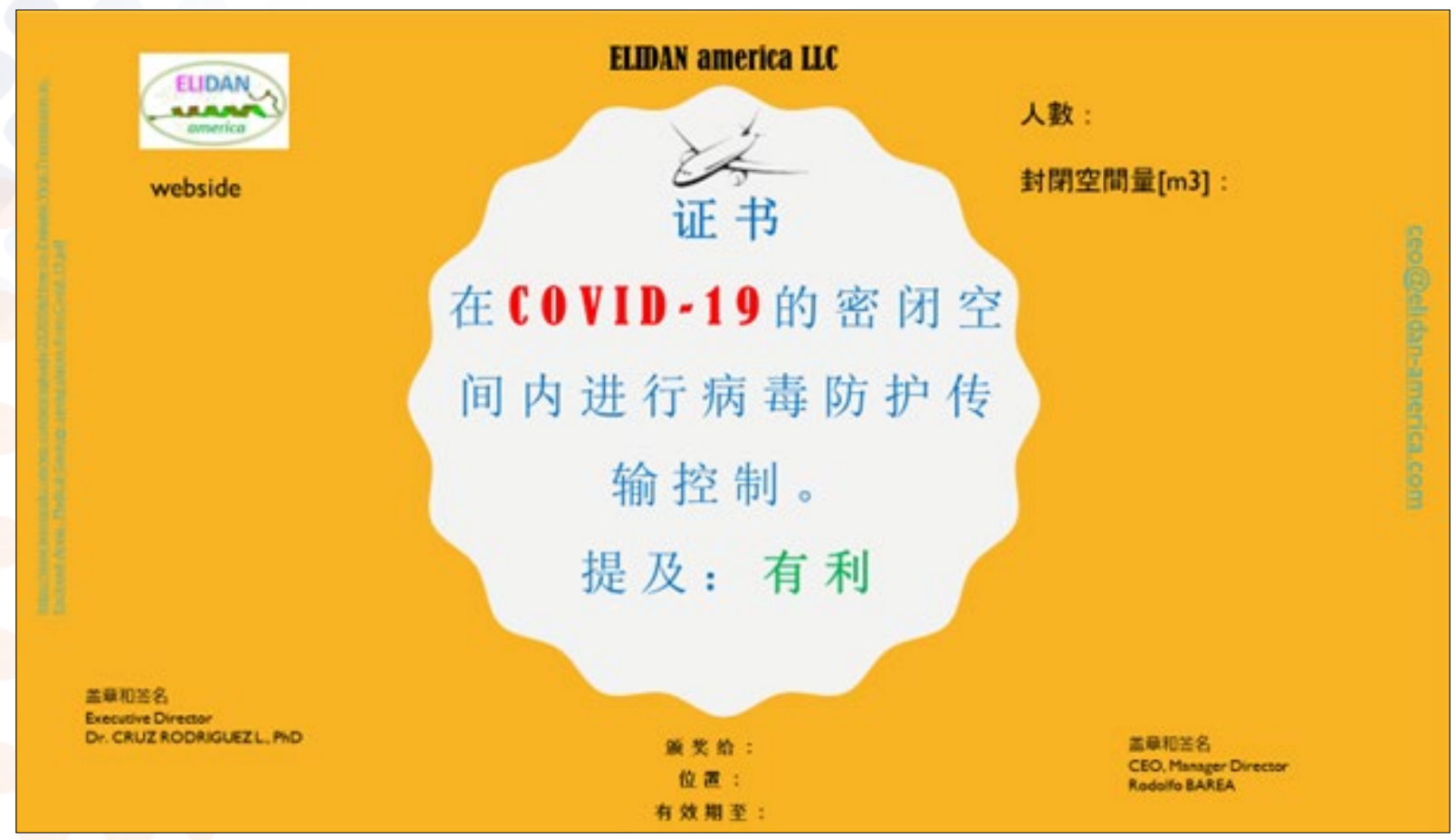

\section{Annexe 14}

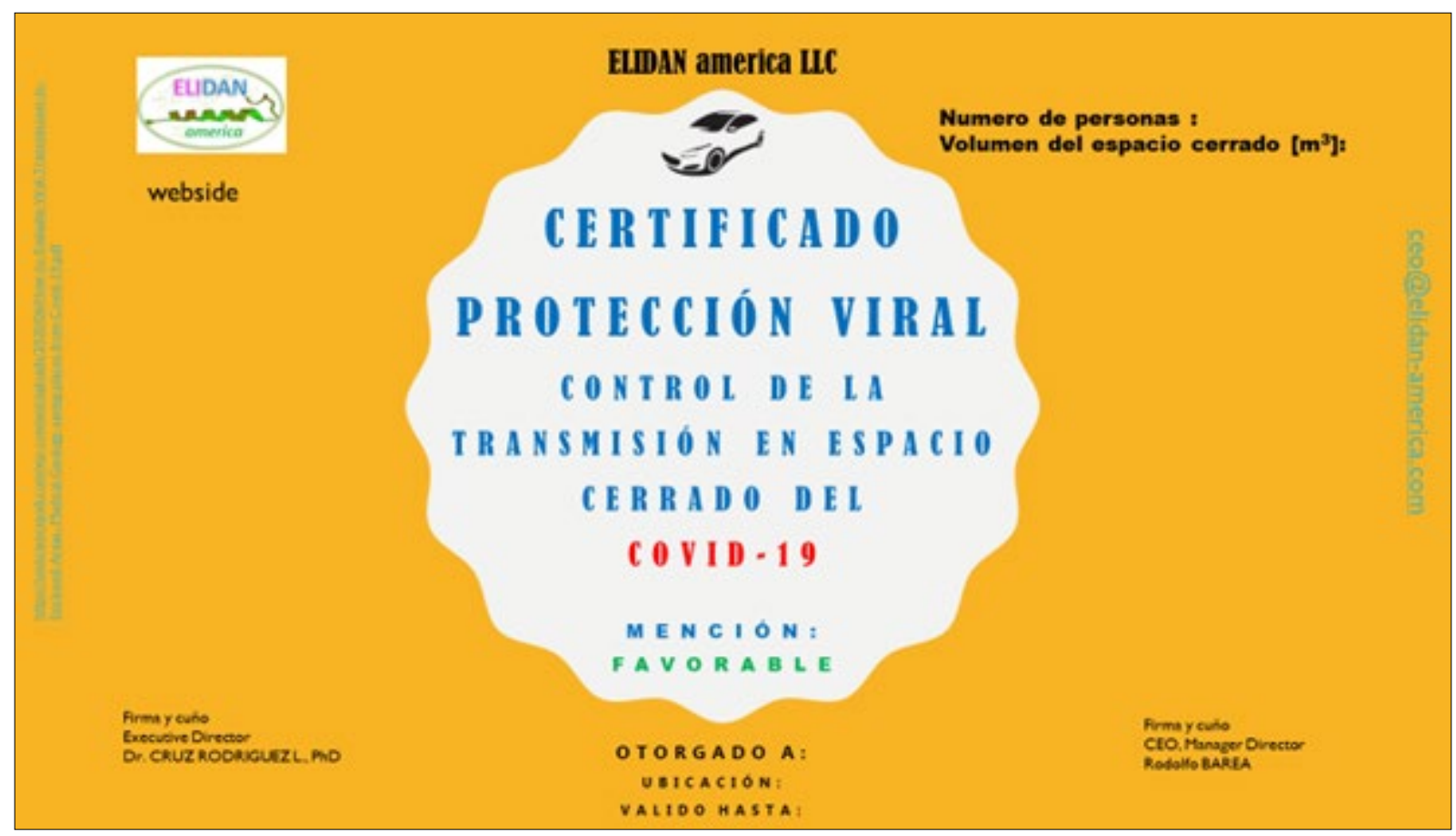




\section{Annexe 15}

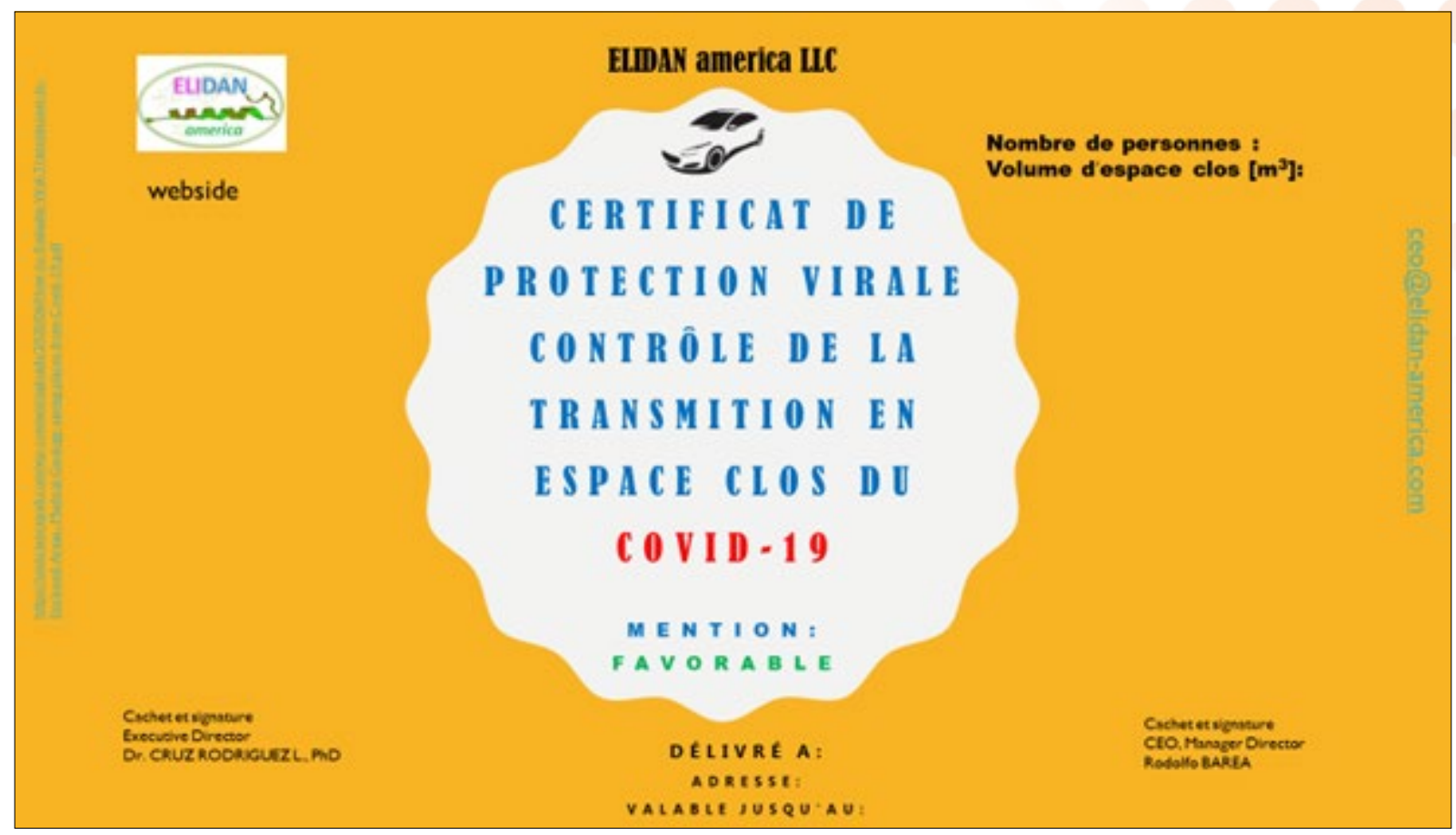

\section{Annexe 16}

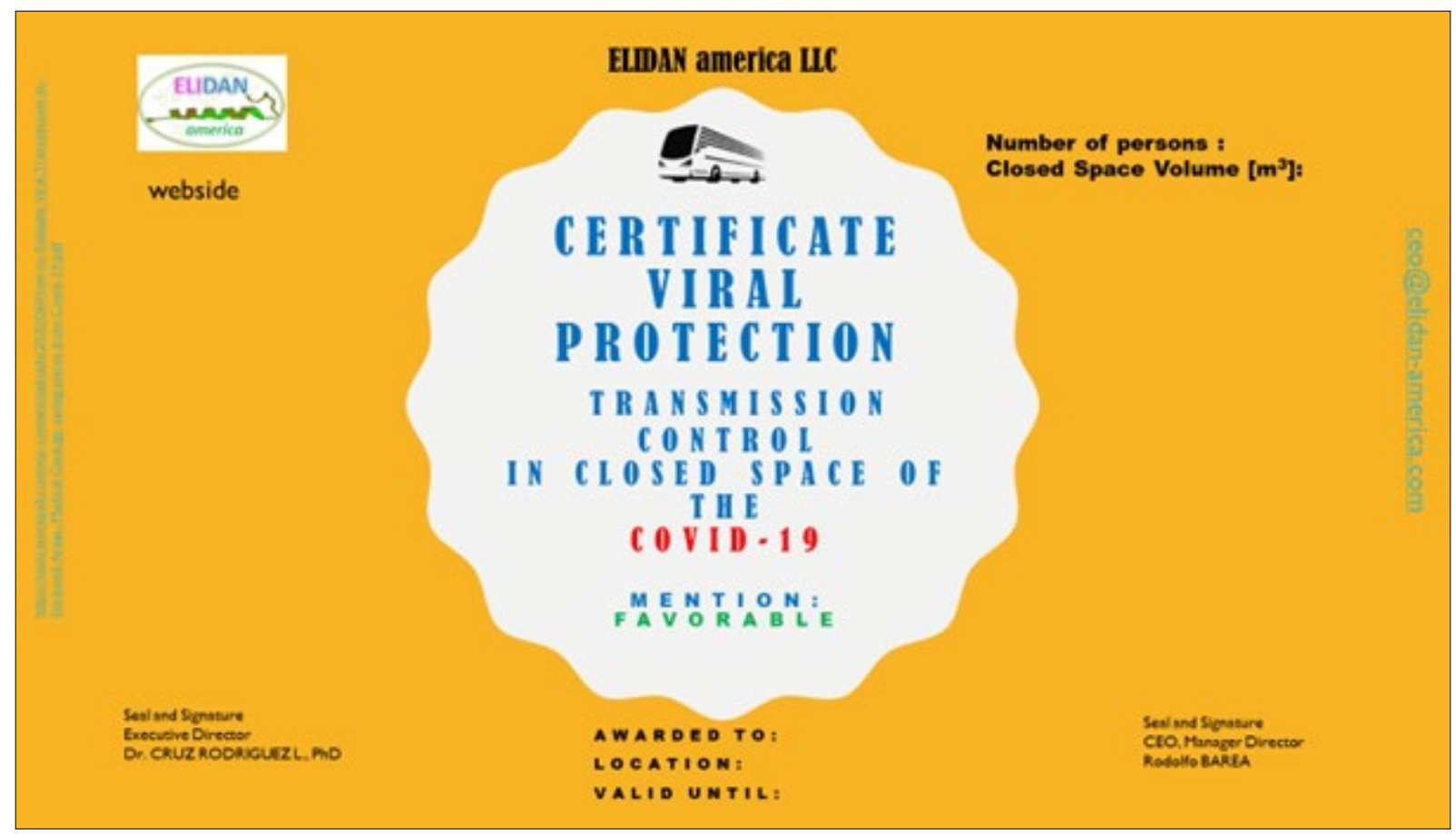




\section{Annexe 17}

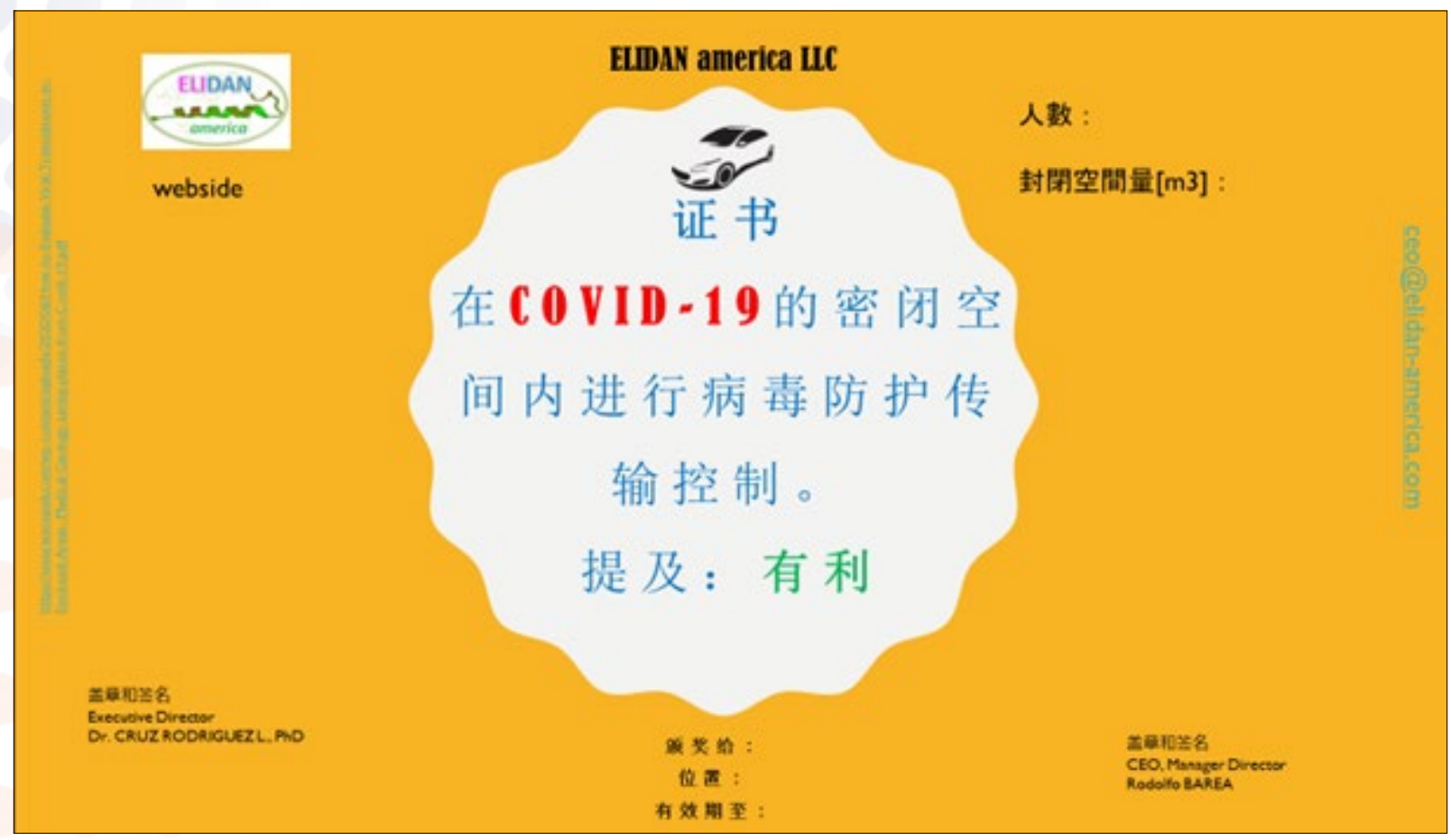

\section{$\underline{\text { Annexe } 18}$}

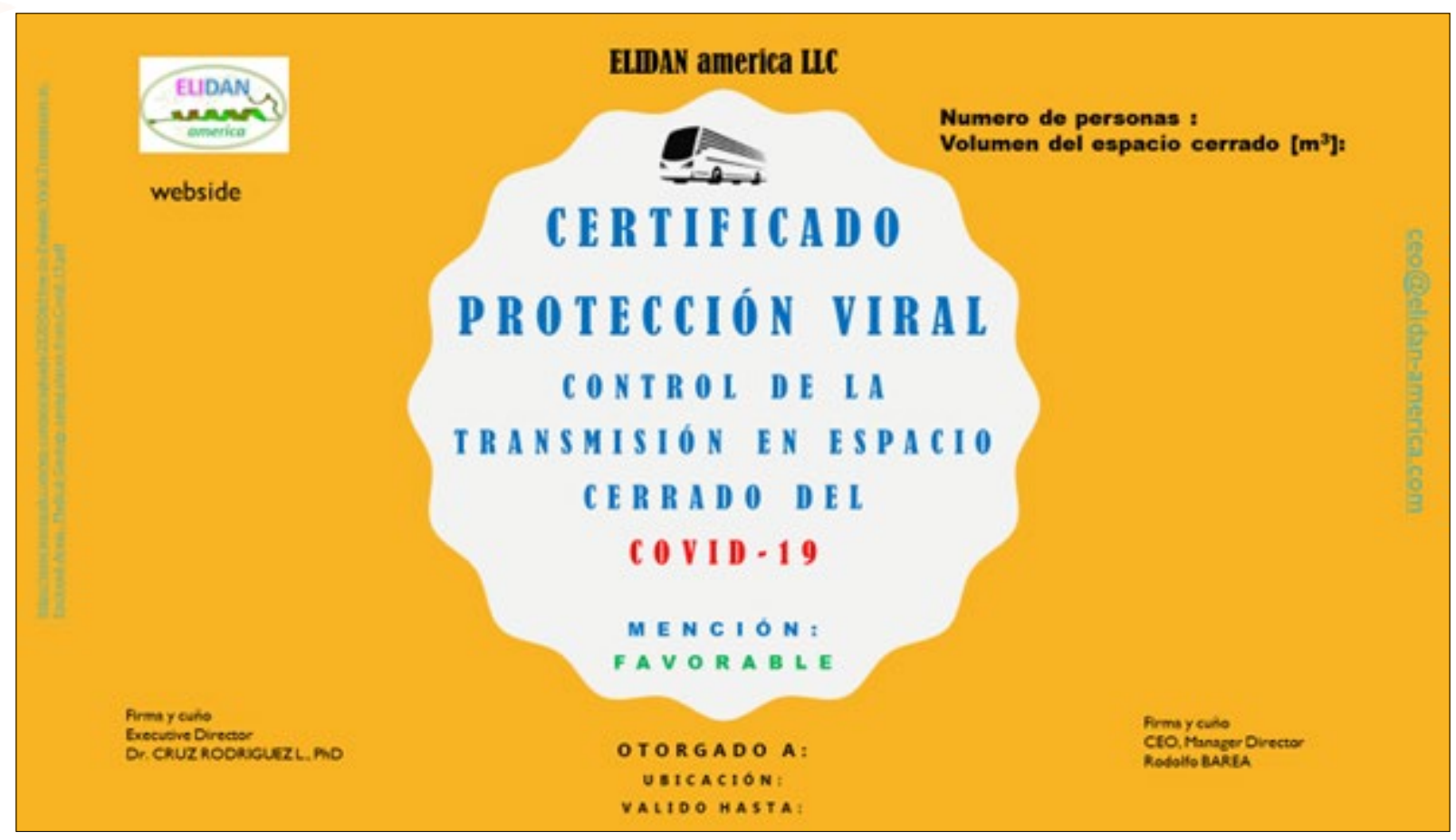




\section{Annexe 19}

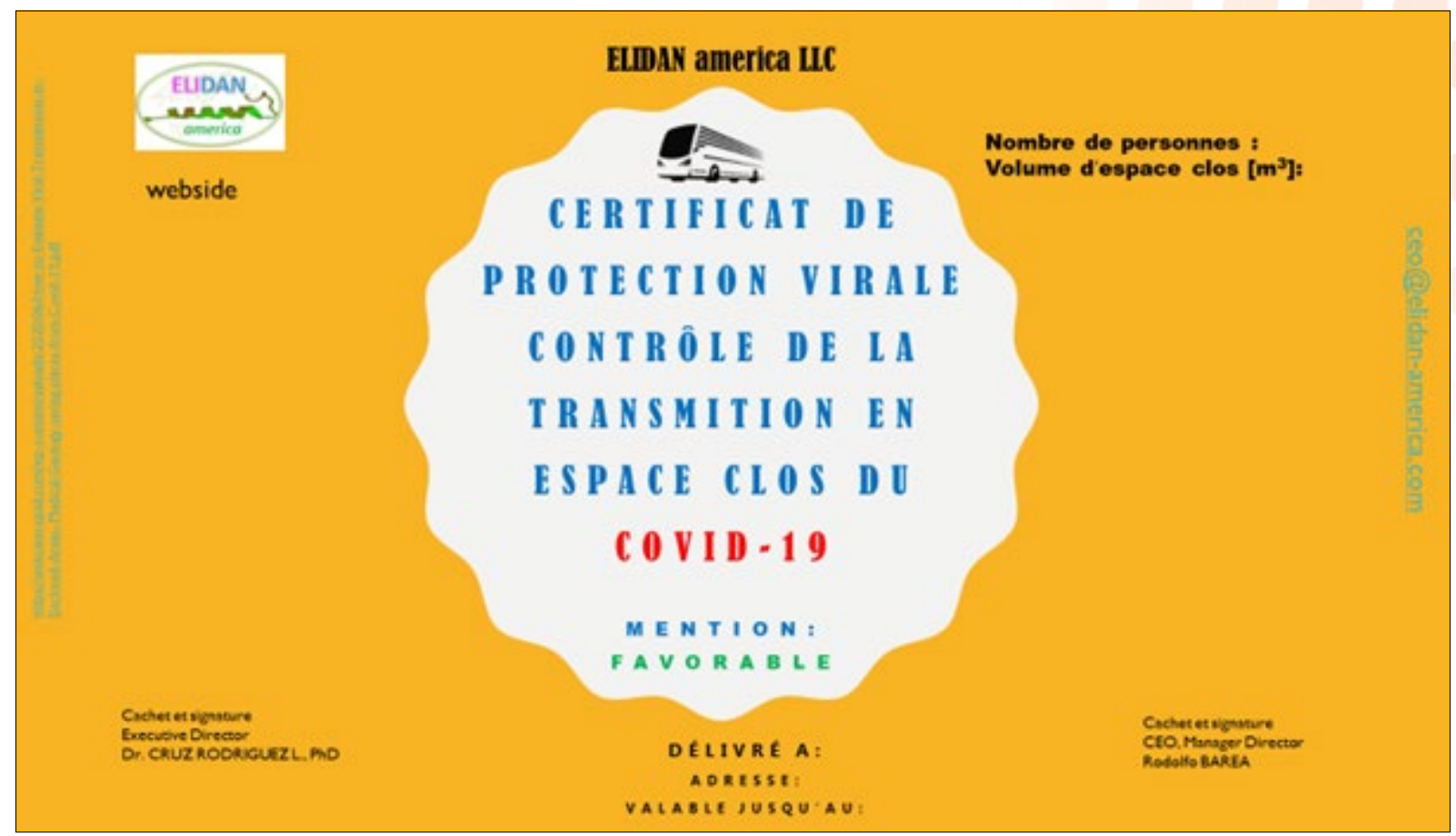

Annexe 20

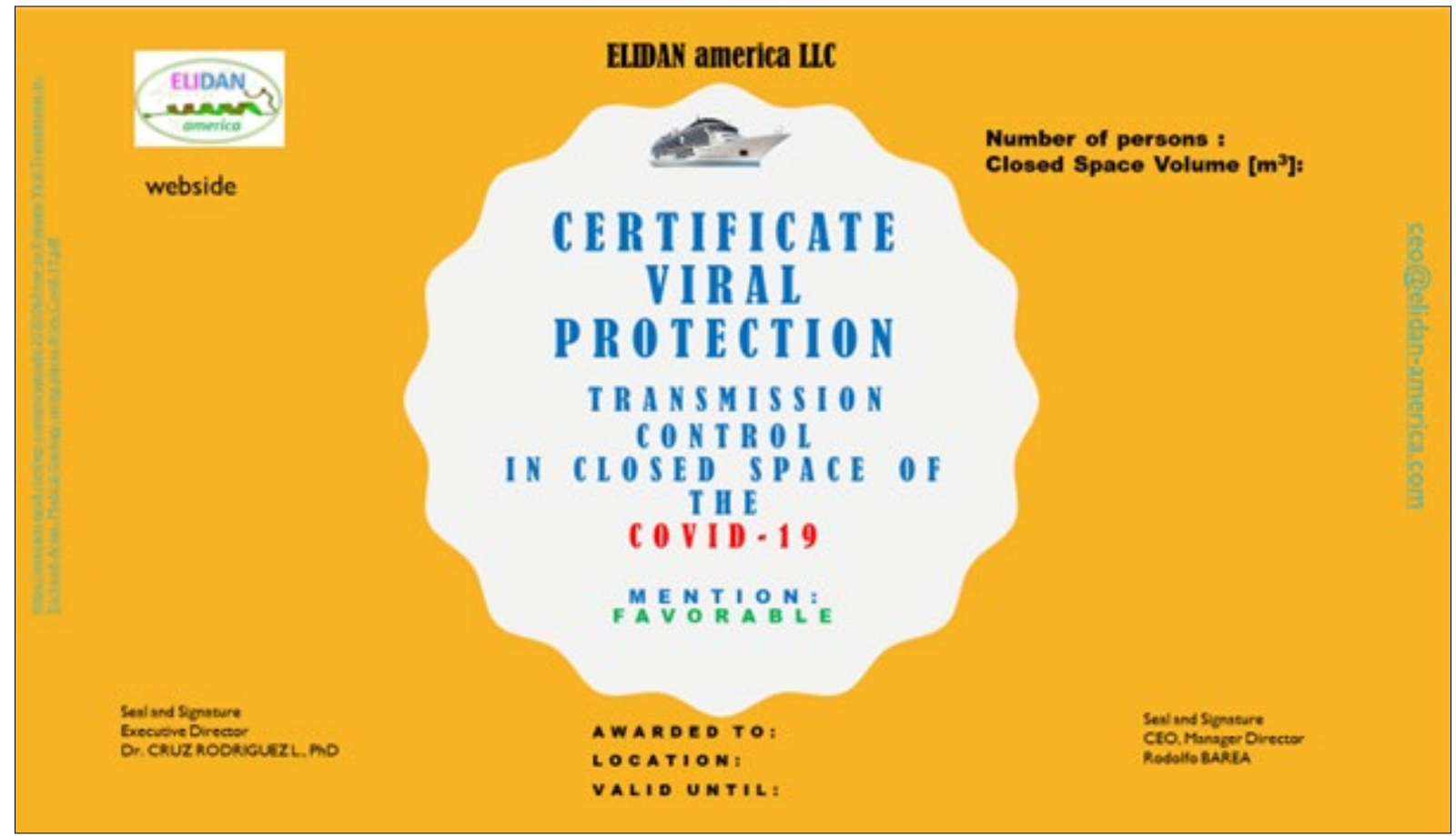


Annexe 21

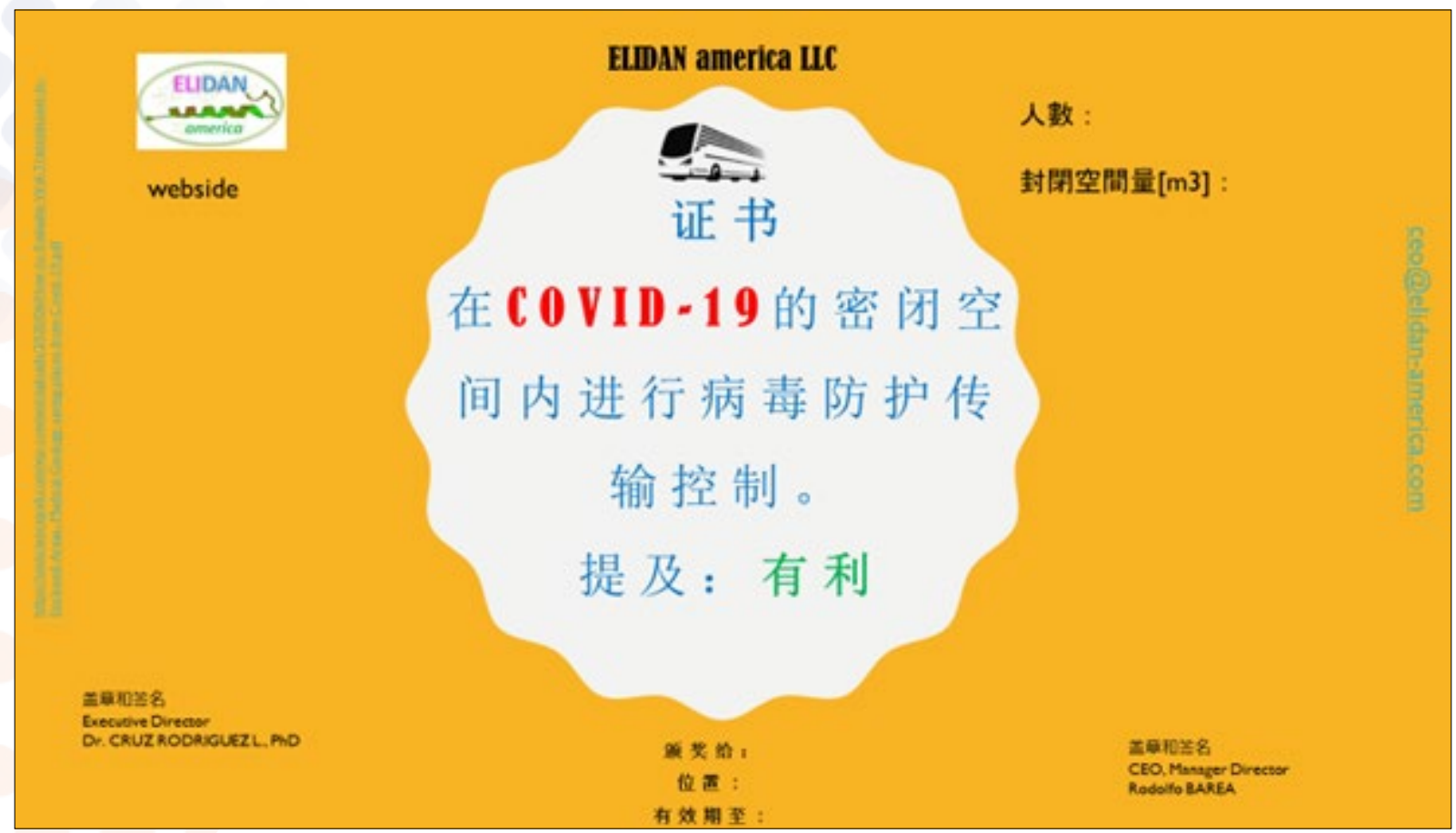

Annexe 22

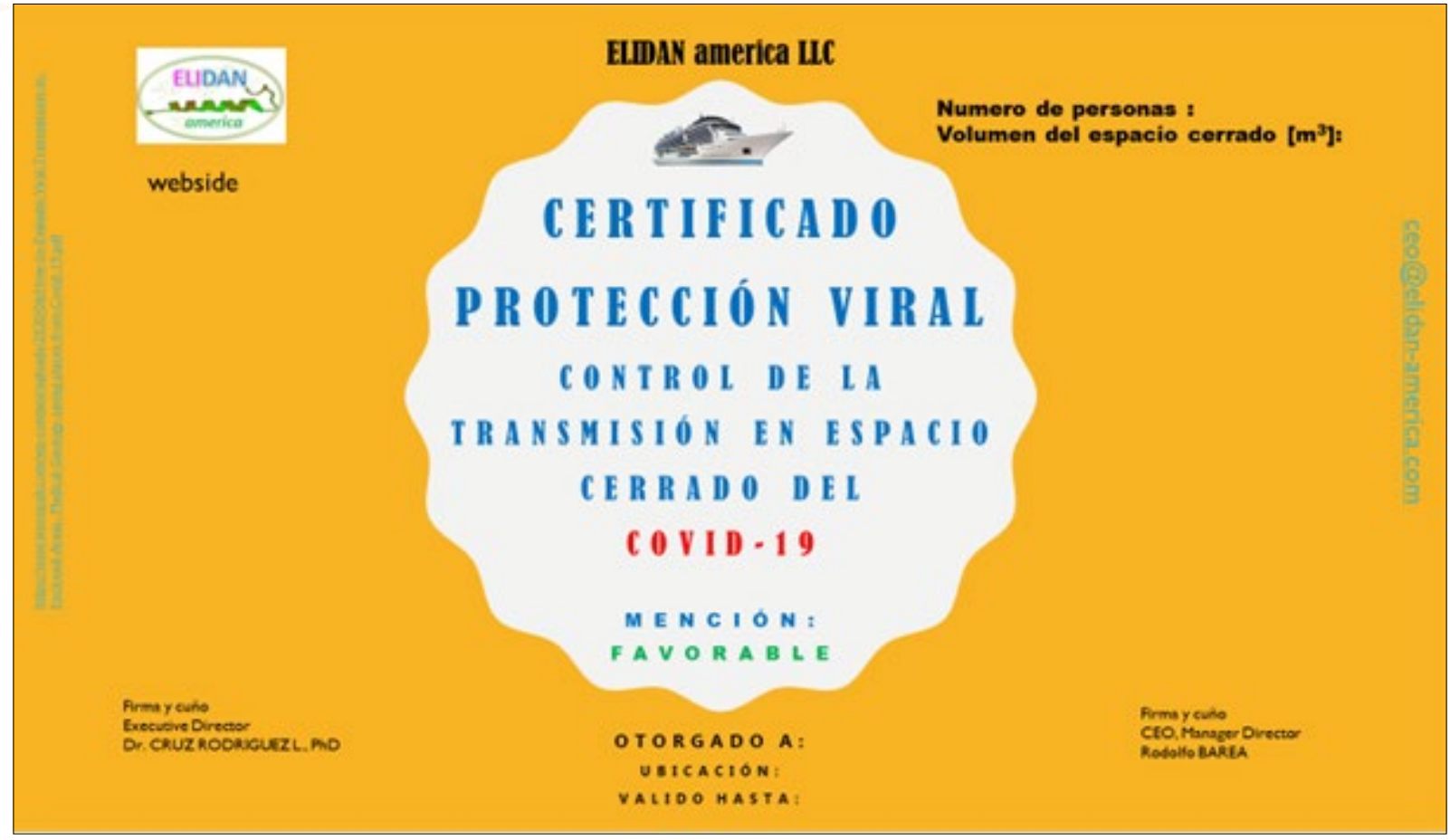




\section{Annexe 23}

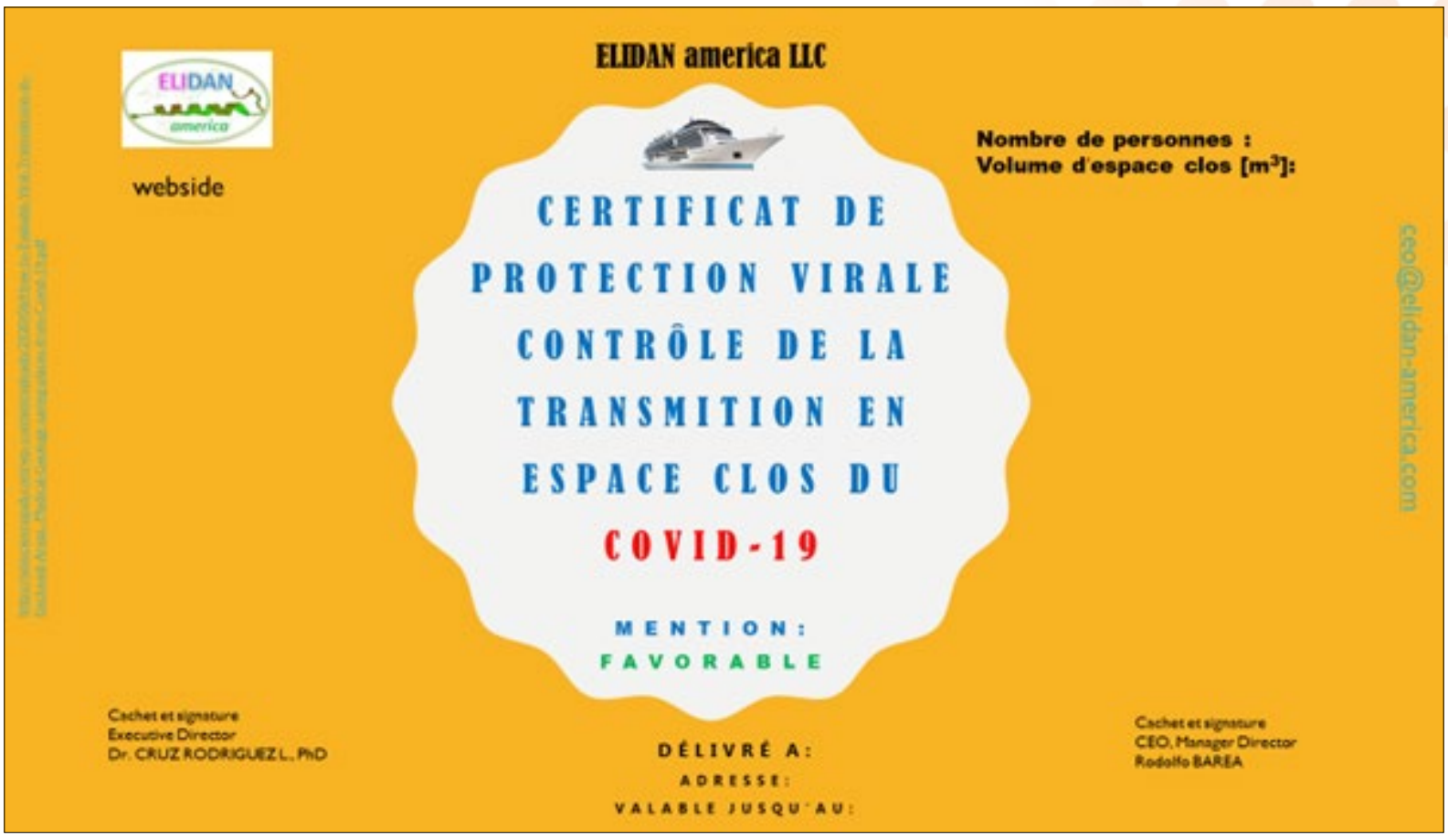

\section{Annexe 24}

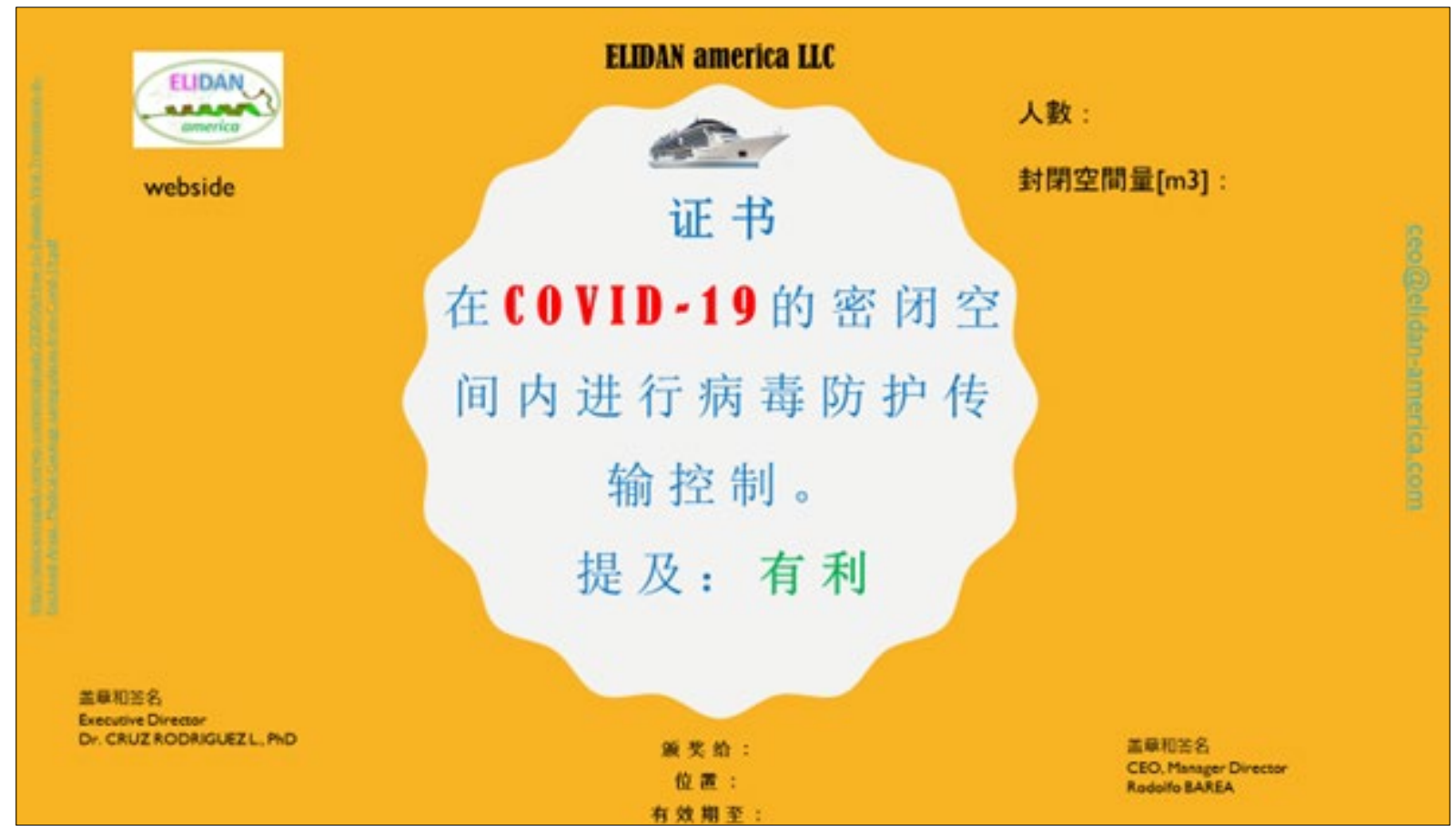

